\title{
1 Coccolithophore cell biology: chalking up progress
}

3 Authors:

4 *Alison R. Taylor (taylora@uncw.edu)

5 Department of Biology and Marine Biology, University of North Carolina

6 Wilmington, North Carolina, 28403, USA

8 Colin Brownlee (cbr@mba.ac.uk)

9 The Marine Biological Association, The Laboratory, Citadel Hill, Plymouth, PL1 2PB,

10 UK.

11 and

12 School of Ocean and Earth Sciences, University of Southampton, National

13 Oceanography Centre, Southampton SO14 3ZH, UK.

14

15 Glen Wheeler (glw@mba.ac.uk)

16 The Marine Biological Association, The Laboratory, Citadel Hill, Plymouth, PL12PB,

17 UK

18

19 *author for correspondence

20

21

22

23 Keywords: Calcification, dimethylsulfoniopropionate, Emiliania, haptophyte, 24 mixotrophy, vesicle, virus.

25

26 


\section{Table of Contents}

$2 \quad \mathbf{1 . 0}$ Introduction to coccolithophores

$3 \quad \mathbf{2 . 0}$ Evolution of coccolithophores

$4 \quad 3.0$ Cell biology, lifecycle and ecological niches

5 3.1 Life cycle transitions

63.2 Mixotrophy

$7 \quad \mathbf{4 . 0}$ Biotic interactions

$8 \quad 4.1$ Bacteria

94.2 Viruses

$10 \quad 5.0$ Coccolithophore metabolism and physiological diversity

11 5.1 Carbon metabolism

$12 \quad 5.2$ Osmoprotectants

$13 \quad 6.0$ Recent insights into functional roles of calcification

$14 \quad 6.1$ Defense from pathogens and grazers

$15 \quad 6.2$ Modulation of diffusion boundary layer

$16 \quad 6.3$ Modulating the light field and energy balance

$17 \quad$ 7.0 Opening the 'black box' of vital effects in coccolithophores

$18 \quad 8.0$ Calcification mechanism

198.1 Ultrastructure and role of intracellular membranes

208.2 Role of organic components in calcification

218.2 .1 Coccolith associated polysaccharide

8.2.2 Coccolith associated proteins

8.3 Ion transport

24

8.4 The problem of protons

25

8.5 New paradigms for calcification

$26 \quad 9.0$ Coccolithophore distribution, diversity and adaptation

$27 \quad \mathbf{1 0 . 0}$ Concluding remarks 


\section{Abstract}

2 Coccolithophores occupy a special position within the marine phytoplankton due to

3 their production of intricate calcite scales, or coccoliths. They are major

4 contributors to global ocean calcification and long-term carbon fluxes. The

5 intracellular production of coccoliths requires modifications to cellular

6 ultrastructure and metabolism that are surveyed here. In addition to calcification,

7 which appears to have evolved with a diverse range of functions, a number of other

8 remarkable features that likely underpin the ecological and evolutionary success of

9 coccolithophores have recently been uncovered. These include complex and varied

10 life cycle strategies related to abiotic and biotic interactions, together with a range

11 of novel metabolic pathways and nutritional strategies. Together with knowledge of

12 coccolithophore genetic and physiological variability, these findings are beginning

13 to shed new light on species diversity, distribution, and ecological adaptation.

14 Further advances in genetics and functional characterization at the cellular level will

15 likely to lead to rapid acceleration of this understanding. 


\section{$1 \quad 1.0$ Introduction to coccolithophores}

The coccolithophores are an important group of marine phytoplankton,

3 characterized by their covering of external calcium carbonate plates (coccoliths).

4 They emerged relatively recently in evolutionary timescales (estimated at around

$5300 \mathrm{Ma}$ ) and have become major contributors to marine ecosystems and global

6 biogeochemical cycles. The most abundant coccolithophore species in modern

7 oceans is Emiliania huxleyi which can form massive blooms in temperate and

8 subpolar regions, producing up to $10^{8}$ cells $\mathrm{L}^{-1}$. Together with other ecological

9 significant species, the coccolithophores contribute up to half of the estimated $\sim 1.6$

$10 \mathrm{Pg}_{\text {year }}^{-1} \mathrm{CaCO}_{3}$ produced in the pelagic zone (Balch et al. 2007). Coccolithophores

11 influence surface ocean biogeochemistry by fixing a significant amount of carbon

12 through photosynthesis (biological C-pump) and through release of $\mathrm{CO}_{2}$ during

13 coccolith formation (carbonate counter pump) (Rost \& Riebesell 2004). The ballast

14 of sinking coccolithophore calcite increases the burial flux of organic matter (Ziveri

15 et al. 2007). Coccolithophores also contribute to global sulphur cycling through their

16 production of dimethylsulphoniopropionate (DMSP).

17 Coccolithophores exhibit remarkable metabolic features that underpin their

18 ability to successfully complete with other species in the surface oceans. Most

19 notably (and unlike most calcifying organisms) production of their calcite coccoliths

20 occurs in an intracellular compartment, with subsequent secretion onto the cell

21 surface (Figure 1) (Raven \& Giordano 2009). A better understanding of their

22 ecophysiology through studies of phenotypic and physiological plasticity, cell

23 metabolism, microbial interactions, and mechanisms of calcification will lead to an

24 improved understanding of their biogeochemical impacts and responses to

25 environmental change (O'Brien et al. 2016). Here we highlight some of the most

26 recent advances in these areas and offer suggestions of potential avenues for further

27 research.

\subsection{Evolution of coccolithophores}

30 Coccolithophores belong the Haptophyta lineage of eukaryotes, the position

31 of which in the eukaryote tree of life has been much debated. Recent multigene 
1 phylogenies place the haptophytes as a sister group to the centrohelids in the

2 Haptista, which shows some association to the Stramenopile-Alveolate-Rhizarian

3 (SAR) supergroup but excludes cryptophytes (Burki et al. 2016). Haptophytes

4 possess a plastid of red algal origin, although the mechanism through which this has

5 been acquired is also the subject of considerable debate. A recent study suggests

6 that plastids of red algal origin in many photosynthetic eukaryotes may have arisen

7 from serial endosymbiotic events, with haptophytes acquiring their plastid from an

8 ochrophyte (photosynthetic stramenopile) ancestor (Stiller et al. 2014). This

9 hypothesis is in alignment with both ultrastructure and pigment associations

10 between these two groups and presumably occurred early in the evolution of

11 haptophytes as chloroplast acquisition by the aplastidic ancestral cell is estimated to

12 be around $\sim 1100$ Ma (De Vargas et al. 2007), although it is clear that much remains

13 to be learnt about haptophyte evolution.

14 Calcification (the precipitation of calcium carbonate) occurs in diverse

15 eukaryote lineages, suggesting that this trait has evolved on multiple independent

16 occasions (Raven \& Giordano 2009). It is likely that calcification emerged in the

17 coccolithophores close to the divergence of the Calcihaptophycidae and

18 Prymnesiales (around $310 \mathrm{Ma}$ ) (Liu et al. 2010), with the earliest fossil

19 heterococcoliths and holococcoliths dated at $220 \mathrm{Ma}$ and 185 Ma respectively (De

20 Vargas et al. 2007). Calcification in the haptophytes may have evolved

21 independently on more than one occasion, as the phylogenetic position of

22 Braaudosphaera, which produces atypical pentagonal nannoliths, remains uncertain

23 (Hagino et al. 2016). The elevated Mg content of the pentaliths of Braarudosphaera

24 suggests that they are formed extracellularly (Hagino et al. 2016), although the

25 inability to grow this species in culture has hampered more detailed investigations

26 into its physiology and its evolutionary origins. Loss of calcification appears to have

27 occurred at least once in the coccolithophores, as the Isochrysidales contain

28 numerous non-calcifying lineages (e.g. Isochrysis). The calcifying members of the

29 Isochrysidales (Emiliania, Gephyrocapsa) also lack holococcoliths in their haploid

30 life cycle stages, suggesting either this trait evolved after the divergence of the

31 Isochrysidales or it was lost in this lineage. Some members of the Coccolithales 
1 (Pleurochrysis, Hymenomonas) also lack holococcoliths, supporting independent 2 loss.

3 Whether there were strong co-evolutionary relationships between the 4 emergence of calcification in haptophytes and the physico-chemical properties of 5 the oceans remains unclear (Raven \& Giordano 2009). A recent study revisited the

6 hypothesis that intracellular calcification evolved as a strategy to avoid cytotoxicity 7 of $\mathrm{Ca}^{2+}$ under the higher levels of $\mathrm{Ca}^{2+}$ in which coccolithophores arose. A calcifying

8 strain of E. huxleyi showed resilience to increased levels of $\mathrm{Ca}^{2+}$ representative of the

9 Cretaceous, whereas several non-calcifying phytoplankton and a non-calcifying

10 strain of E. huxleyi were unable to tolerate these higher $\mathrm{Ca}^{2+}$ levels (Muller et al.

11 2015). This most likely demonstrates the efficiency of the $\mathrm{Ca}^{2+}$ transport and

12 sequestration system in calcifying coccolithophores that can overcome the

13 additional burden of $\mathrm{Ca}^{2+}$ influx imposed under these conditions. Whether the

14 higher environmental $\mathrm{Ca}^{2+}$ in which coccolithophores evolved acted to select for the

15 evolution of an entire intracellular calcification system remains highly speculative.

16 As Raven and Crawfurd (2012) point out, low free cytosolic [ $\left.\mathrm{Ca}^{2+}\right]$ environment

17 evolved early in eukaryote evolution, well before the emergence of intracellular

18 calcification in coccolithophores.

\section{$20 \quad 3.0$ Cell biology, life cycle and ecological niches}

\section{$21 \quad 3.1$ Life cycle transitions}

22 Coccolithophores exhibit both calcified haploid and diploid life cycle phases

23 that can reproduce asexually (Frada et al. 2009, Houdan et al. 2004, Nöel et al. 2004,

24 Young et al. 2005). Diploid cells produce structurally complex calcite crystal

25 heterococcoliths, and dominate natural populations. In many species the periodic

26 haploid phase produces holococcoliths made up of simple calcite rhombohedra

27 (Geisen et al. 2002, Young et al. 1999). Transitional coccospheres comprising holo-

28 and heterococcoliths have been described for most major taxonomic groups,

29 primarily from field specimens (Cros et al. 2000, Geisen et al. 2002, Young et al.

30 2005), suggesting coccolithophores readily undergo life phase transitions in natural

31 populations. There are a few examples of species within the Pleurochrysidaceae and 
1 Hymenomonadacae in which the heterococcolith bearing phase alternates with a

2 non-calcifying haploid phase (Fresnel 1994, Nöel et al. 2004).

It has been proposed that nutrient poor pelagic waters favour motile haploid

4 holococcolithophore assemblages, whereas diploid cells are better adapted for

5 warmer, nutrient rich coastal waters (Oviedo et al. 2015). Nutrient driven diploid-

6 haploid niche partitioning may also underlie the depth distributions of

7 coccolithophores, as observed in the NW Mediterranean, with nutrient-depleted

8 upper oligotrophic waters favouring haploid holococcolith-bearing cells and deeper

9 nutrient rich waters favouring diploid heterococcolith-bearing cells (Cros \& Estrada

10 2013, Oviedo et al. 2015). Accordingly, the diploid Coccolithus braarudii and

11 Calcidiscus leptoporus, sustain higher growth rates than haploid motile cells under

12 high inorganic nutrient levels (Houdan et al. 2006). Moreover, transitions from

13 haploid cells to heterococcolith diploid cells of the oceanic Calyptrosphaera

14 sphaeroidea could be induced by increasing trace-metals and vitamins in the culture

15 medium (Nöel et al. 2004). Decreased temperature was also found to cause diploid-

16 to-haploid transitions in this species (Nöel et al. 2004). Switching to a haploid, and

17 potentially mixotrophic mode of nutrition presumably enables these cells to sustain

18 growth rates that would otherwise not be possible under inorganic nutrient

19 limitation (see below). Consistent with this, growth of haploid cells of $C$. braarudii

20 and $C$. leptoporus is stimulated by addition of organic $\mathrm{C}$, and they are known to

21 actively phagocytose bacteria (Houdan et al. 2006). Increased turbulence inhibits

22 growth of haploid motile Coccolithus braarudii and induces phase transitions to the

23 diploid non-motile phase (Houdan et al. 2006). Finally, both laboratory and field

24 experiments suggest a shift from susceptive diploid, to resistant (non-calcifying)

25 haploid E. huxleyi is promoted by viral infection (Frada et al. 2008, Frada et al.

26 2012), implying alternating life history phases could be a crucial response to the

27 presence of pathogens that ensures long term persistence of the resident population

28 (Figure 2).

29 The alternating haploid-diploid life cycle of coccolithophores, combined with

30 the quite distinct physiological capabilities between these two cell types, likely

31 represents a successful niche partitioning strategy under varying abiotic and biotic 
1 pressures. The haploid phase is also the precursor to sexual reproduction through

2 syngamy, that potentially contributes to micro-adaptation in response to the

3 prevailing conditions. The high genomic variability among diploid calcifying $E$.

4 huxleyi strains (Read et al. 2013) points to a strong adaptation signal among extant

5 isolates. Interestingly, a recent study showed the haploid gene content of diploid

6 strains varied considerably among biogeographical isolates. Using sequencing and

7 competitive genome hybridization Von Dassow and colleagues (2015) demonstrate

8 the haploid genome content was diminished in some diploid strains. For example,

$923 \%$ of a set of $E$. huxleyi genes associated with cilia or flagella function (including 3

10 of the critical dynein heavy chain proteins) are missing from the genome sequence

11 of CCMP1516, suggesting that it has lost the ability to form functional flagella (von

12 Dassow et al. 2015). Whether this loss occurred during the $\sim 20$ years this strain

13 remained in culture under stable high nutrient conditions is unclear. However, a

14 targeted PCR of 83 diploid strains isolated from different oceanographic regions

15 showed that 37 strains associated with warmer oligotrophic waters lacked two

16 dynein heavy chain genes essential for flagella motility. This suggests the ability to

17 undergo phase transitions to motile haploid cells was not advantageous for $E$.

18 huxleyi under these generally warmer, stable and low nutrient conditions (von

19 Dassow et al. 2015). This finding is seemingly at odds with the studies in

20 holococcolith-bearing species described above, that demonstrate oligotrophic

21 conditions favor the transition to the haploid stage. A more detailed understanding

22 of the ecological drivers for life-cycle transitions in coccolithophores is needed. It

23 will be interesting to see whether strains that have lost the ability to produce motile

24 haploid cells are susceptible to the E. huxleyi virus (see below).

\subsection{Mixotrophy}

Bacterivory in oligotrophic ecosystems is dominated by picoeukaryote algae

28 (Hartmann et al. 2012) with small flagellated non-calcifying haptophyte taxa

29 contributing up to $30 \%$ of bacterivory in oligotrophic coastal waters (Unrein et al.

30 2014). These haptophytes have been shown to acquire and incorporate $\mathrm{C}$ and $\mathrm{N}$

31 from labeled Prochlorococcus and Synechococcus implying they can be significant 
1 grazers of picocyanobacteria, significantly redirecting $\mathrm{C}$ within marine food webs

2 (Ward \& Follows 2016). Given the mixotrophic origins of the haptophytes (De

3 Vargas et al. 2007), it is not surprising that coccolithophores possess the genes

4 associated with the maintenance of a phagosomal pathway. While phagocytotic

5 behavior has generally been attributed to the haploid motile (and haptonemal-

6 bearing) life phase of coccolithophores, transcripts of genes related to phagocytosis

7 in E. huxleyi have been shown to be more abundant in diploid non-motile, calcifying

8 cells (Rokitta et al. 2011). If phagocytosis occurs in these diploid cells, it does so in

9 the absence of a haptonemal appendage and while the cell is covered with a layer of 10 coccoliths.

11 Much is still be learned about the nutritional capability of coccolithophores,

12 to determine whether they can be significant grazers of bacteria and to assess their

13 ability to occupy alternate ecological niches in order to overcome inorganic nutrient

14 limitation. This is of particular interest for climate change scenarios whereby

15 increased sea surface temperature and stratification may favor mixotrophic modes

16 of nutrition (Mitra et al. 2014, Wilken et al. 2013).

\section{$18 \quad 4.0$ Biotic interactions}

\section{$19 \quad 4.1$ Bacteria}

Although there are several well-described mutualistic interactions between eukaryote phytoplankton and bacteria (see (Cooper \& Smith 2015) and references

22 therein), functional interactions between bacteria and coccolithophores remain

23 largely uncharacterized. A survey of bacteria associated with cultured E. huxleyi and

24 C. pelagicus $f$ braarudii highlighted a species rich community of $\alpha$ - and $\gamma$ -

25 proteobacteria with several taxa in common with other phytoplankton including

26 Marinobacter and Marivita (Green et al. 2015). Of interest are bacteria that may be

27 more specific to the unique coccolithophore 'phycosphere'. These include

28 hydrocarbon degrading bacteria, and a Bacteroidetes diversity dominated by

29 Sphingobacteria as opposed to the Flavobacteria that are more typical of diatoms

30 and dinoflagellates. The presence of species of Acidobacteria known to be associated 
1 with organisms that secrete carbonate biominerals, led to the proposal that these

2 acid-secreting bacteria could degrade coccolith calcite and access CAPs as a source 3 of organic carbon (Green et al. 2015).

$4 \quad$ How coccolithophore-bacteria associations influence nutrient exchange and

5 carbon flow are unknown. However, comparing axenic and non-axenic cultures, Van

6 Oostende et al. (Van Oostende et al. 2013) show the presence of bacteria in cultures

7 of P-limited E. huxleyi results in altered composition of dissolved polysaccharides

8 and a greater production of extracellular particulate organic matter. Thus, bacterial

9 activity can modify the pattern of organic matter produced and released by

10 coccolithophores, thereby influencing export production. Moreover, intracellular

11 pools of lipids and alkenones are likely dependent on bacterial assemblages

12 associated with coccolithophores (Segev et al. 2016), which warrants further

13 investigation, given the importance of the alkenones as temperature paleoproxies.

14 Evidence of mutualistic interactions between bacteria and coccolithophores

15 is limited. Seyedsayamdost and co-workers recently described a mutualism

16 between a bloom-associated rosebacter P. gallaceiensis and E. huxleyi in which the

17 bacterium produces antibiotics and auxin, which are presumed to support a growth

18 enhancing relationship in which the bacterium derives C- and S- from DMSP

19 produced by the alga (Seyedsayamdost et al. 2011). However, P. gallaceiensis

20 opportunistically switches from mutualist to pathogen as E. huxleyi approach

21 stationary or senescing stages. The cue for this so-called 'Jekyll-and-Hyde' transition

22 by $P$. gallaceiensis is $p$-coumaric acid, a lignin-like compound released by the aging $E$.

23 huxleyi cells. In response to $p$-coumaric acid, P. gallaceiensis, produces a suite of

24 secondary metabolites including potent algicides (roseobacticides)

25 (Seyedsayamdost et al. 2011). This complex metabolic interaction has an

26 interesting twist as isotope labeling demonstrates the bacteria incorporates the $p$ -

27 coumaric acid into the biosynthetic pathway of the roseobacticides, resulting in a

28 virulent hybrid molecule derived from both host and pathogen (Seyedsayamdost et

29 al. 2014). Moreover, the DMSP derived from the alga during the mutualistic phase is

30 important in providing a source of $\mathrm{S}$ for toxin production (Seyedsayamdost et al.

31 2014) (Figure 3). 
The potential for detrimental interactions with bacteria is also demonstrated

2 by the high sensitivity of E. huxleyi to the algicidal marine $\gamma$-Proteobacteria

3 Pseudoalteromonas piscicida (Harvey et al. 2016). In this case, a soluble quorum

4 sensing alkyl-quinolone was purified and found to mediate mortality in E. huxleyi at

$5 \mathrm{nM}$ concentrations, whereas the green alga Dunaliella tertiolecta and the diatom

6 Phaeodactylum tricornutum were insensitive to this compound. Nevertheless, all

7 three species were susceptible to exudates of $P$. piscicida suggesting the production

8 of a cocktail of compounds that confers broad algicidal activity (Harvey et al. 2016).

9 These recent developments demonstrate that coccolithophores have a

10 complex and underexplored repertoire of symbiotic, mutualistic and antagonistic

11 interactions with bacteria. Characterizing these interactions is important to

12 determine the relative contributions of bacteria and viruses to coccolithophore

13 population dynamics and associated biogeochemical cycles (Figure 3).

\subsection{Viruses}

16 The complete genome sequence and transcription profile of a large DNA 17 virus (EhV-86) that infects E. huxleyi (Wilson et al. 2005) yielded important insights

18 into the host-virus dynamic. Both mesocosm (Pagarete et al. 2011) and mesoscale

19 studies have demonstrated the ability of the virus to regulate bloom dynamics in

20 natural populations, especially under relatively stable physical conditions (Lehahn

21 et al. 2014). Research by several groups over the last decade has focused on the viral

22 infection mechanism (Figure 4).

23 An important early observation of the EhV-86 genome was the presence of a

24 suite of genes, derived from host-virus horizontal gene transfer (Monier et al. 2009),

25 coding for the biosynthesis of sphingolipids, which are expressed during the lytic

26 infection cycle (Wilson et al. 2005). It has since been shown that the virus

27 reprograms host lipid metabolism, stimulating production of highly saturated

28 triacylglycerols (Malitsky et al. 2016), suppressing host glycosphingolipid pathway,

29 and promoting production and incorporation of virus encoded sphingolipids

30 (vGSLs) (Rosenwasser et al. 2014). At least in the early stages of infection, the 
1 virions bud from the host and retain a lipid envelope derived from the host

2 (Mackinder et al. 2009), but highly enriched in saturated triacylglycerols (Malitsky

3 et al. 2016) and containing vGSLs (Fulton et al. 2014, Vardi et al. 2009).

4 The infection mechanism of EhV appears to involve recognition of

5 components in lipid raft microdomains of the host membrane. Uninfected cells have

6 a diverse lipid raft proteome the composition of which is rapidly altered on infection

7 by EhV (Rose et al. 2014). Of particular interest is a Toll-like interleukin receptor

8 protein present in host lipid rafts that may interact with a virus-associated C-type

9 lectin, possibly mediating attachment and viral translocation across the membrane.

10 Whether lipid rafts play a role in both viral entry and egress has not been fully

11 resolved. Susceptibility to infection appears also to be strongly correlated with the

12 presence of sialic-acid GSLs in diploid cells (Hunter et al. 2015). The absence of

13 sGSLs from the lipidome of resistant haploid cultures suggests a mechanism that

14 could explain the basis for the diploid-to-haploid 'escape strategy' during virus-

15 induced bloom termination (Frada et al. 2008, Frada et al. 2012). The events that

16 trigger a switch to haploid and resistant cells on viral infection are yet to be

17 established.

18 A further innovation of EhV is the proviral utilization of the host autophagy

19 pathway. Schatz and coworkers recently demonstrated the lytic phase of EhV

20 infection corresponds to increased expression of autophagy-related genes (ATG

21 genes) along with ultrastructural changes (multi membrane vesicles), increased

22 lysosomal activity, and a protein marker (Atg8) for autophagy associated with the

23 membranes surrounding viral particles (Schatz et al. 2014). Viral entry and DNA

24 replication are unaffected by inhibitors of autophagy, whereas assembly and exit

25 from the cell are suppressed, suggesting co-opting of the autophagy pathway is a

26 late stage cellular interaction that promotes intracellular encapsulation of the

27 virions in modified host membranes and propagation by burst release (Schatz et al.

28 2014)(Figure 4). Viral particles are coated with several layers of host membrane

29 enriched with TAG and viral GSLs, and facilitate the envelope fusion of viruses

30 particles with uninfected host membranes (Mackinder et al. 2009) 
Terminal events following infection, and in response to increasing vGSLs

2 include increased reactive oxygen production (Evans et al. 2006), rapid degradation

3 of cellular components, reduction of photosynthetic efficiency, and induction of host

4 metacaspases and caspase activity that is necessary to promote viral production

5 (Figure 4). This suggests co-evolution of the host-virus resulted in strong selection

6 for viruses that co-opt the phytoplankton PCD pathway in their infection strategy

7 (Bidle et al. 2007, Vardi et al. 2009). These cellular events have since been

8 confirmed in natural populations of E. huxleyi (Vardi et al. 2012).

9 How phytoplankton viruses propagate in natural ecosystems is not well

10 understood, though the coccolithophore model has yielded important discoveries.

11 Multiple viral transmission mechanisms likely play a critical role the ecology of $E$.

12 huxleyi. Both zooplankton (Frada \& Vardi 2015) and aerosolisation (Sharoni et al.

13 2015) have the potential to increase dispersal of competent EhV particles through

14 the water column and over large scales respectively, facilitating rapid infection and

15 termination of coccolithophore blooms. Local diffusion and encounter rates of viral

16 particles determine infection of the host cell at the microscale. Zooplankton-

17 mediated dispersal may be an important determinant of infection at the mesoscale

18 due to their non-random diffusivity in a patchy prey landscape (Figure 4). The half-

19 life of aerosolized virus particles exposed to sunlight/UV is only $20 \mathrm{~min}$.

20 Nevertheless, the 1000 x greater diffusivity of aerosols compared to particles in the

21 water column suggest aerosols could be a highly effective transmission mechanism

22 over larger oceanographic realms.

23 Advances in understanding the host-virus infection dynamic have enabled

24 deeper ecological questions to be addressed. For example, the vGSLs have

25 successfully been used as in-situ biomarkers for viral infection in natural

26 populations (Vardi et al. 2012), allowing interrogation at the population level to

27 reveal the degree of genetic and metabolic variability among natural host-virus

28 populations. Such biological and ecological insights will enable viral impacts on

29 nutrient fluxes, microbial food webs, and C export from the surface ocean to be

30 more clearly defined and to be incorporated effectively into ecosystem models

31 (Weitz et al. 2015). 


\subsection{Coccolithophore metabolism and physiological versatility}

Coccolithophores exhibit unique metabolic traits that contribute to their physiological versatility. Genomic, proteomic, metabolomic and biochemical approaches have been largely restricted to E. huxleyi and may not reflect the full

6 metabolic diversity of other coccolithophore lineages.

\subsection{Carbon metabolism}

In most photosynthetic organisms, the major carbon storage compounds are $\alpha-/ \beta$-glucans (e.g. starch in land plants and green algae). Although E. huxleyi

11 produces a water soluble $\beta$-glucan, quantitative analyses of carbon fluxes during

12 photosynthesis suggest that $\beta$-glucan is only a minor $\operatorname{sink}(<1 \%)$ for fixed carbon

13 (Tsuji et al. 2015). Instead, carbon is predominately stored in low molecular weight

14 compounds (such as mannitol), acidic polysaccharides, alkenones and other lipids

15 (Obata et al. 2013, Tsuji et al. 2015). The absence of significant storage glucans and

16 the primary accumulation of carbon into mannitol and alkenones are a distinct

17 feature of carbon metabolism in E. huxleyi (Obata et al. 2013, Tsuji et al. 2015).

18 Other unique aspects of coccolithophore metabolism are evident from the

19 presence of novel enzymes or their unusual localization. For example, pyruvate

20 carboxylase is commonly found in the cytoplasm or mitochondria of eukaryotes,

21 where it plays an important role in replenishing TCA cycle intermediates. However,

22 in E. huxleyi pyruvate carboxylase was found to be plastid-localized, leading to the

23 proposal that it plays a novel role by acting to regulate carbon flux to amino acid

24 skeletons within the plastid (Tsuji et al. 2015). Transcriptomic studies suggest that

25 E. huxleyi, like the diatoms, possesses an ornithine-urea cycle (OUC) playing a

26 similar role in N-redistribution during N-limitation (Mckew et al. 2015, Rokitta et al.

27 2014). N-limitation also led to elevated expression of a mitochondrial malate-

28 quinone oxidoreductase (MQO) in E. huxleyi (Rokitta et al. 2014). This enzyme

29 enables direct transfer of electrons from malate to quinone, representing an

30 alternative input to the mitochondrial electron transport chain that is not

31 dependent on the activity of the TCA cycle. MQO is found in dinoflagellates and some 
1 other alveolates, but is notably absent from diatoms (Danne et al. 2013, Rokitta et al.

2 2014). Interestingly, GC-MS based metabolite profiling studies in E. huxleyi could not

3 detect malate, whereas malate accumulates significantly in the cells of land plants

4 (up to $350 \mathrm{mM}$ ) (Obata et al. 2013). These findings suggest that malate plays a very

5 different role in coccolithophore metabolism and that coccolithophores are much

6 less reliant on the activity of the TCA cycle than land plants.

\section{$8 \quad 5.2$ Osmoprotectants}

9 Coccolithophores accumulate a range of metabolites that can act as

10 osmoprotectants. These include polyols (mannitol), quaternary ammonium

11 compounds (glycine betaine (GBT) and homarine), and the tertiary sulphonium

12 compound dimethylsulphonioproprionate (DMSP) (Gebser \& Pohnert 2013). DMSP

13 is a major metabolite in many haptophytes, although it is absent from some

14 haptophyte lineages such as Pavlova, which accumulate cyclitols (e.g. D-1,4/2,5-

15 cyclohexanetetrol) instead (Kobayashi et al. 2007). DMSP production by

16 coccolithophores and other marine phytoplankton plays an important role in the

17 global sulphur cycle, as DMSP is the precursor of the climate active gas, dimethyl

18 sulphide (DMS). Both DMSP and DMS act as powerful infochemicals that can

19 influence a wide variety of biotic interactions at both the micro- (e.g. chemotaxis of

20 bacteria and alteration of zooplankton trophic behavior) and macroscale (e.g. as

21 chemoattractants for birds, turtles and fish) (Fredrickson \& Strom 2009, Garren et

22 al. 2014, Savoca \& Nevitt 2014, Seymour et al. 2010, Steinke et al. 2006, Wolfe et al.

23 1997). Coccolithophores accumulate high amounts of DMSP (up to $400 \mathrm{mM}$ in $E$.

24 huxleyi), the concentration of which is influenced by light intensity, salinity, growth

25 phase and diel cycle and also differs significantly between strains (Darroch et al.

26 2015, Franklin et al. 2010, Keller et al. 1999, Steinke et al. 1998). Gebser and

27 Pohnert (2013) demonstrated that the major zwitterionic metabolites in E. huxleyi

28 were DMSP, GBT and homarine and that the ratio of these osmolytes was

29 remarkably constant over a range of salinities (ratios of approximately 100:6:10).

30 This suggests that all three of these osmolytes are regulated by similar mechanisms

31 in response to changes in salinity. N-limitation results in much lower cellular 
1 concentrations of the quaternary ammonium compounds (GBT and homarine),

2 although little or no compensatory increase in the cellular concentration of DMSP

3 was observed under these conditions (Keller et al. 1999).

$4 \quad$ Bacteria and algae both contain enzymes (DMSP lyases) that can cleave

5 DMSP to generate DMS which contributes a major flux of sulphur to the atmosphere.

6 Significant progress in the past decade has led to the identification a range of

7 bacterial DMSP lyases that are thought to play a major role in DMS production in the

8 oceans (Moran et al. 2012). However, the recent identification of an E. huxleyi gene

9 product, Alma1, as a specific and highly active algal DMSP lyase indicates that

10 coccolithophores can directly cleave the DMSP they produce to generate DMS and

11 acrylate (Alcolombri et al. 2015). The E. huxleyi enzyme shares no sequence

12 similarity with the DMSP lyases found in bacteria, although related enzymes are

13 found in marine phytoplankton that accumulate DMSP, including other haptophytes

14 (e.g. Phaeocystis antartica, Prymnesium parvum) and dinoflagellates (e.g.

15 Symbiodinium) (Alcolombri et al. 2015). Levels of Alma1 gene expression and

16 protein abundance in E. huxleyi correlated very closely with DMSP lyase activity. The

17 discovery of Alma1 fills an important missing link in the marine sulphur cycle and

18 will aid estimations of the relative contribution of phytoplankton and bacteria to

19 global DMS production. The Alma1 protein has two conserved cysteines essential

20 for enzyme activity and activity is sensitive to oxidants. This suggests that changes

21 in cellular redox status may modulate DMSP lyase activity, which may be linked to

22 the proposed antioxidant role for DMSP (Darroch et al. 2015, Sunda et al. 2002), as

23 rates of DMSP cleavage would be lowered in response to oxidative stress.

\section{$25 \quad 6.0$ Recent insights into functional roles of calcification}

26 The most striking metabolic specialization in coccolithophores is calcification

27 itself. Despite this, the functional role(s) of calcification in coccolithophores remain

28 uncertain (Raven \& Crawfurd 2012, Taylor \& Brownlee 2016, Young 1994) with

29 several hypotheses relating to nutrient uptake, photosynthesis and protection from

30 biotic and abotic stressors. Nevertheless, some recent studies have provided

31 intriguing new insights. A potential role for calcification in utilization of $\mathrm{HCO}_{3}$ as a 
1 source of $\mathrm{CO}_{2}$ for photosynthesis has been widely discussed (Berry et al. 2002,

2 Raven \& Crawfurd 2012). Although photosynthesis and calcification interact

3 metabolically (see section 6.3), an obligatory dependence of photosynthesis upon

4 calcification, at least in E. huxleyi, is not well supported by recent studies (Herfort et

5 al. 2004, Leonardos et al. 2009, Trimborn et al. 2007). Indeed, under low DIC

6 conditions photosynthesis may compete with calcification for $\mathrm{HCO}_{3}$ - (Bach et al.

7 2013).

\section{$9 \quad$ 6.1 Defense from grazers and pathogens,}

10 While the coccosphere may be expected to have a protective role, the

11 evidence currently available remains equivocal. For example, the presence of a

12 coccosphere does not prevent ingestion of E. huxleyi by either copepods or

13 microzooplankton predators (Harris 1994), although highly modified articulated

14 coccoliths of members of the Syracosphaeraceae could act as a more direct

15 mechanical deterrence (Young et al. 2009). Recent evidence showed that haploid,

16 non-calcifying E. huxleyi cells possessed inducible grazing defense properties

17 whereas calcifying cells did not, indicating complex relationships between prey and

18 grazer activity (Kolb \& Strom 2013). Recently, (Harvey et al. 2015) showed

19 significant reduction in grazer growth rate feeding on calcified versus non-calcified

20 E. huxleyi strains, the proposed mechanism being reduced digestion efficiency in the

21 food vacuole/phagosome when feeding on calcified cells compared to non-calcifying

22 prey. Thus calcification is integrated into a range of traits including production of

23 DMSP and other undefined metabolites that can contribute to the degree of top-

24 down control at the population level. In the case of pathogens, susceptibility and

25 infection rates appear to be determined by a variety of metabolic interactions

26 unrelated to calcification (see section 6.3). Indeed, diploid calcifying cells of $E$.

27 huxleyi were shown to be suseceptible to viral infection whereas haploid cells were

28 not, leading to the "Cheshire cat" diploid-to-haploid 'escape strategy' hypothesis

29 (Frada et al. 2008).

$31 \quad 6.2$ Modulation of diffusion boundary layer 
Comparison of isogenic calcifying and non-calcifying isolates of E. huxleyi

2 showed that the non-calcifying strain exhibited higher growth rates than the

3 calcifying strain under stable, nutrient-replete conditions (Bartal et al. 2015),

4 consistent with the considerable energetic cost of calcification. However, under

5 moderately turbulent growth conditions, the ability to produce coccoliths conferred

6 mechanical resilience and improved affinity for nitrate acquisition, possibly via

7 stabilization of the diffusion boundary layer at the cell surface. A similar role for

8 diatom frustules has been proposed based on diffusional bias caused by their fine-

9 scale architecture that enhances uptake in patchy nutrient environments (Mitchell

10 et al. 2013). These observations emphasize the need to better understand the

11 microenvironment between the coccosphere and cell membrane and how the

12 coccoliths and associated structures can influence this. cell either in a photoprotective or photo-enhancing role (Nanninga \& Tyrrell 1996,

17 Quinn et al. 2005). Recent work on isolated E. huxleyi coccoliths suspended in

18 solution and aligned in a magnetic field showed that both enhancement and

19 inhibition of incident light scattering is possible although the effect on light intensity

20 was less than 5\% (Mizukawa et al. 2015). Similar conclusions can be drawn from

21 experiments comparing photosynthetic parameters in calcifying diploid E. huxleyi

22 with non-calcifying haploid cells (Houdan et al. 2005). Light saturation kinetics are

23 similar in both cell types, although photoinhibition was only observed in the haploid

24 non-calcifying strain.

25 The remarkable resistance to photoinhibition by calcified strains of $E$. huxleyi

26 led to the hypothesis that calcification may provide an alternative energy sink in

27 response to high light levels. Inhibition of calcification in low $\mathrm{Ca}^{2+}$ seawater led to

28 down regulation of photosynthetic pigments and C-fixation (Xu \& Gao 2012) and

29 these cells were also more susceptible to UV radiation (Xu et al. 2011). Moreover,

30 sudden increases in light intensity from sub-saturating growth irradiance enhanced

31 calcification fixation within minutes in diploid E. huxleyi suggesting a mechanism for 
1 rapid dissipation of excess energy additional to changes in light harvesting pigment

2 content (Ramos et al. 2012). The relatively stable proteome of $E$. huxleyi during

3 photoacclimation from sub-saturating to supra-saturating light levels (McKew et al.

4 2013a, McKew et al. 2013b) implies at steady-state, calcification machinery operates

5 substantially below its maximum potential, and can respond rapidly to altered

6 environmental conditions.

$7 \quad$ Regardless of the environmental drivers that may have led to the evolution of

8 intracellular calcification, the selective advantage of calcite production in modern

9 coccolithophores is likely to be multifarious, and remains enigmatic. Understanding

10 these functional roles of calcification is important but will continue to be a challenge

11 given the interdependency of the cellular and metabolic processes involved.

\subsection{Opening the 'black box' of vital effects in coccolithophores}

14 Well-preserved coccolithophore calcite and alkenones in ocean sediments

15 are used to reconstruct physicochemical properties of the surface oceans. The

16 carbonate structures produced by coccolithophores and foraminifera have been

17 utilized to develop a range of geochemical proxies. This is because elements and

18 isotopes in the mineral theoretically reflect their abundances in seawater, and allow

19 for paleoreconstructions of environmental conditions in the surface oceans. Marine

20 biogenic $\mathrm{CaCO}_{3}$ proxies include $\mathrm{Mg} / \mathrm{Ca}, \mathrm{Sr} / \mathrm{Ca}{ }^{18} \mathrm{O} /{ }^{16} \mathrm{O}$ (paleothermometry) and

$21{ }^{13} \mathrm{C} /{ }^{12} \mathrm{C}$ (DIC and ocean productivity) and they are increasingly relevant tools to

22 understand past climate events and to inform ecological scenarios that may arise

23 through the predicted future Anthropocene climate (Levin et al. 2015).

24 The physiological processes that mediate biogenic $\mathrm{CaCO}_{3}$ precipitation play a

25 critical role in stable isotope incorporation that can dramatically deviate from

26 thermodynamic predictions (de Nooijer et al. 2014). These so-called 'vital effects'

27 are due to the biologically controlled transport of ions and organic compounds into

28 the compartment that promotes a saturated state favoring nucleation and calcite

29 precipitation. Foraminifera $\mathrm{CaCO}_{3}$ proxies such as the $\mathrm{Mg} / \mathrm{Ca}$ paleothermometer are

30 well advanced and robust (Hermoso 2014, Levin et al. 2015) although considerable

31 variation in Mg incorporation appears to be driven by cellular metabolic processes 
1 (Spero et al. 2015), and isotopic fractionation of $\delta^{13} \mathrm{C}$ and $\delta^{18} \mathrm{O}$ is also significantly

2 influenced by photo-symbionts (Takagi et al. 2015). Coccolithophore proxies have

3 been covered extensively by Hermoso (Hermoso 2014). The multiple ion

4 transporters and endomembrane compartments that are involved in the trans-

5 cellular pathway of inorganic substrates for intracellular coccolith production have

6 a significant, but largely uncharacterized influence on ion and isotope fractionation.

7 Species differences in calcite precipitation, associated organic material, and

8 coccolith digenesis are also poorly understood. Further implementation of robust

9 coccolith proxies requires an improved mechanistic understanding of calcification.

\section{$11 \quad$ 8.0 Calcification Mechanism}

12 The mechanism of coccolithophore calcification has been studied extensively

13 since the pioneering work of Paasche more than 50 years ago (Paasche 1968) and

14 advances in the intracellular model of calcification have been covered in several

15 comprehensive reviews (Brownlee \& Taylor 2004, Brownlee et al. 2015, Paasche

16 2001, Westbroek et al. 1989, Young et al. 1999, Young et al. 2005). Despite this, the

17 mechanistic details of coccolith production are surprisingly incomplete.

\subsection{Ultrastructure and role of intracellular membranes}

Coccoliths are produced in an intracellular Golgi-derived vacuole (generally

21 referred to as the coccolith vesicle, CV) that has a complex relationship with the

22 endomembrane system. The basic sequence of events has been well described at

23 the ultrastructural level in several species (see Figure 1b-d), but the mechanism by

24 which coccoliths are produced and secreted is not fully understood. The

25 endomembrane system most likely plays an important role in supply of the

26 inorganic and organic substrates for calcification through targeted trans-Golgi

27 trafficking and via the direct association with the CV (Figure 5). For example, a

28 system of anastomosing tubules known as the reticular body is closely associated

29 with the coccolith compartment and important for delivery of organic and inorganic 
1 substrates for calcification and in determining fine-scale morphology of the mineral 2 structure (Drescher et al. 2012, Taylor et al. 2007).

The scale of secretion of the coccolith itself - coccoliths are transferred to the 4 cell surface via a single secretory event - suggests potentially novel features of exo5 and endocytosis are required to co-ordinate the process and efficiently retrieve the 6 membrane (see Figure 1b-d). Evidence of a modified membrane trafficking system 7 (MTS) was recently found in the haptophyte complement of post-Golgi adaptor 8 protein (AP) complexes (Lee et al. 2015). Losses of AP3, which targets

9 multivesicular body (MVB) and lysosome, and AP5, which targets trans-Golgi 10 network and MVB, but multiple expansions of AP4 that mediates trans-Golgi

11 network trafficking to the plasma membrane and endosomes were common among 12 calcifying and non-calcifying haptophytes (Lee et al. 2015), suggesting a specialized

13 MTS may have been necessary for the genesis of haptophyte body scales prior to the 14 evolution of calcified scales. A further unique AP4 expansion within calcifying 15 haptophytes indicates additional specialization of the MTS specific for

16 biomineralization. Moreover, diploid specific expression of several syntaxin/SNARE

17 homologs that function in vesicle engagement and fusion with target membranes

18 (Mackinder et al. 2011), implies that additional specificity in the MTS could be

19 achieved through differential transcription and translation of MTS genes in

20 calcifying cells. A closer analysis of expression patterns of MTS related genes and

21 the localization of their proteins during calcification and viral infection could

22 provide important information on the coordination of membrane dynamics during 23 these processes.

$24 \quad$ Regulation of the cytoskeleton must play an important role in directing 25 calcification because it actively interacts with the MTS, may influence the shape of 26 the $\mathrm{CV}$, and probably controls vesicle and cell movements associated with coccolith 27 secretion. However, there is surprising little information on cytoskeletal dynamics 28 of coccolithophores. Inhibitors of actin and microtubules unsurprisingly result in 29 gross distortions of coccoliths (Langer et al. 2010) but the specific role these

30 structures play in calcification have not been resolved. 


\section{$1 \quad 8.2$ Role of organic components in calcification}

\subsubsection{Coccolith associated polysaccharide:}

While proteins are generally the predominant organic components of $\mathrm{CaCO}_{3}$

4 biomineral structures (e.g. corals and molluscs), polysaccharides are the major organic components associated with calcite production in coccolithophores. In $P$.

6 caterae the coccolith associated polysaccharides (CAP) are $2 \%$ of coccolith mass

7 (Okumura et al. 2012) with up to $28 \%$ of ${ }^{14} \mathrm{C}$ incorporation dedicated to

8 extracellular polysaccharide in E. huxleyi, reinforcing their importance in the

9 calcification process (Kayano \& Shiraiwa 2009).

10 The CAPs are acidic in nature, comprising a backbone of D-mannose residues

11 with a series of side chains that include D-ribose, L-arabinose, D-xylose, L-rhamnose

12 and D-galacturonic acid residues and ester-bound sulphate groups (Fichtinger-

13 Schepman et al. 1981, Kayano \& Shiraiwa 2009). The steric arrangement of the

14 carboxyl groups of the acidic residues confers the ability to bind both free $\mathrm{Ca}^{2+}$ and

$15 \mathrm{Ca}^{2+}$ of calcite crystal surfaces (Henriksen et al. 2004). The type of CAP produced

16 appears to be species specific (Borman et al. 1982, Hirokawa et al. 2005, Marsh et al.

17 1992, Ozaki et al. 2007), and even within a single species, CAPs may play distinct

18 roles during coccolith production. For example, in Pleurochrysis carterae acidic

19 polysaccharides (PS1 and PS2) are predominantly associated with excreted

20 coccoliths and thought to play a role in $\mathrm{Ca}^{2+}$ transport and crystal growth, whereas a

21 mannose-, xylose-, and sulphate-rich polysaccharide (PS3), is proposed to play a

22 role in governing morphology during later stages of coccolith development (Marsh

23 et al. 2002). The biosynthetic pathway for CAP production is unknown, although it is

24 assumed to occur via the endomembrane and Golgi system, with delivery to the

25 developing coccolith compartment via trans-Golgi vesicle transport (Marsh 1994).

26 How CAP regulates coccolith morphology is also poorly understood, although

27 they may in part determine coccolith crystal shape through inhibition of calcite

28 growth at acute steps of calcite crystals (Henriksen et al. 2004, Kayano et al. 2011).

29 Inorganic precipitation experiments demonstrate that $\mathrm{pH}$ and ionic composition of

30 the medium strongly affect the interaction of the CAP with the mineral surface.

31 Selective binding of CAP to the acute step edges of rhombic calcite crystals is 
1 promoted between $\mathrm{pH}$ 3.4-7.7 and in presence of $\mathrm{K}^{+} \mathrm{Na}^{+} \mathrm{Sr}^{2+}$ and $\mathrm{Ca}^{2+}$ ions. CAP

2 attachment to the acute step edges of calcite drives crystal morphology away from

3 the rhombic form, allowing extension along the c-axis (Kayano et al. 2011). Basic $\mathrm{pH}$

4 and presence of $\mathrm{Mg}^{2+}$ prevents site-specific absorption of CAP (Henriksen \& Stipp

5 2009), therefore favoring the rhombic calcite morphology. In E. huxleyi cultures,

6 elevated $\mathrm{Mg}^{2+}$ in the growth medium results in aberrant coccoliths (Herfort et al.

7 2004), whereas elevated $\mathrm{Sr}^{2+}$ does not significantly alter coccolith morphology

8 (Langer et al. 2006). Although it is not possible to extrapolate the concentration of

9 these ions in the medium to the site of calcification, these results are consistent with

10 inorganic experiments that show CAP interactions with calcite are strongly

11 influenced by $\mathrm{Mg}^{2+}$ ions (Henriksen \& Stipp 2009, Henriksen et al. 2004).

12 A future challenge is to understand the ontogenetic and temporal chemistry

13 of the CV. It is conceivable that regulation of calcite morphology is achieved through

14 temporal modulation of CAP interactions with the calcite surface by fluctuations in

$15 \mathrm{CV} \mathrm{pH}$, as well as $\mathrm{Ca}^{2+}$, carbonate species, and other metal cations such as $\mathrm{Mg}^{2+}$.

16 Given the very close association of the of the $\mathrm{CV}$ and endomembranes and the

17 developing calcite crystal (Figure 5), it would be interesting to consider the

18 glycolipid and glycoprotein complement of these membranes, to assess whether

19 membrane associated oligosaccharide residues could play a direct role in altering

20 crystal growth that leads to fine-scale morphological features such as pores

21 (Drescher et al. 2012).

22 In addition to the role of CAPs in the mineralization process itself, their

23 integration into the coccolith structure has important biogeochemical implications.

24 Hassenkam and coworkers (2011) argue the notable lack of thermodynamically

25 favored Ostwald ripening of calcite crystals in coccolith-dominated chalk deposits is

26 due to the large amount of organic material associated with them, a striking

27 observation that illustrates the geological influence of CAP. Indeed, intra-crystalline

28 CAP can be recovered from fossil coccoliths $-70 \mathrm{Ma}$ and retains its ability to interact

29 with calcite surfaces in inorganic experimental systems (Sand et al. 2014). CAPs are

30 also critical in resisting coccolith dissolution, significantly influencing digenesis and

31 the burial flux of inorganic carbon (Hassenkam et al. 2011). Moreover, the stable 
1 and recalcitrant and intra-crystalline organic $\mathrm{C}$ in ancient coccolith deposits

2 suggests a significant fraction is unavailable for remineralization. Given that up to

$3 \sim 15 \%$ of cellular organic $\mathrm{C}$ may be allocated to CAP, this is an important to consider

4 when assessing inorganic/organic $\mathrm{C}$ export. CAP and precursors could also play

5 important role in coagulation of cells and coccoliths, affecting the ballasting of

6 calcite (Chow et al. 2015).

\section{$8 \quad$ 8.2.2 Coccolith associated proteins}

9 Although the role of matrix proteins in coccolith production appears to be

10 limited, and likely confined to the baseplate scale, a gene encoding a glutamic acid,

11 proline and aspartic acid rich protein (GPA) with $\mathrm{Ca}^{2+}$ binding motifs is associated

12 with coccolith morphology in E. huxleyi and G. oceanica (Corstjens et al. 1998). The

13 GPA protein was isolated from coccolith associated polysaccharide fractions

14 suggesting a role in coccolith growth and morphology. Quantitative PCR shows

15 strong regulation of the GPA gene with up-regulation in non-calcifying haploid cells

16 and in calcifying diploid cells in which calcification has been suppressed by low $\mathrm{Ca}^{2+}$

17 treatment (Mackinder et al. 2011). Although counter-intuitive, a number of

18 possibilities could explain this observation, including an inhibitory role for GPA at

19 high concentrations. Without a clearer understanding of how calcification is

20 regulated by organic components in general, it is difficult to draw firm conclusions.

21 The GPA gene has not been detected in the transcriptomes of any other

22 coccolithophore species to date, suggesting pelagic, bloom-forming species in the

23 family Noëlaerhabdaceae may have unique organic regulatory components that

24 underlie mechanistically distinct calcification processes among coccolithophores

25 (See section 8.5).

\section{$27 \quad 8.3$ Ion transport}

28 The calcification process (Figure 5) presents a remarkable case of transport

29 physiology requiring some of the highest sustained trans-cellular fluxes of $\mathrm{Ca}^{2+}$,

$30 \mathrm{HCO}_{3}{ }^{-}$and $\mathrm{H}^{+}$of any known eukaryote cell (Brownlee \& Taylor 2004, Brownlee et al.

31 2015). Comparative transcriptomics have identified transport genes likely to be 
1 specifically associated with calcification (Mackinder et al. 2011, von Dassow et al.

2 2009). Of particular relevance are $\mathrm{Ca}^{2+} / \mathrm{H}^{+}$exchangers (CAX3), a vacuolar $\mathrm{H}^{+}$

3 ATPase and a $\mathrm{Na}^{+}$-dependent $\mathrm{K}^{+} / \mathrm{Ca}^{2+}$ exchanger (NCKX). Inorganic carbon fluxes

4 are likely mediated by a $\mathrm{HCO}_{3}{ }^{-}$transporter(s) in the SLC4 family. Additional

5 constitutive transporters such as $\mathrm{Ca}^{2+}$ channels and $\mathrm{Ca}^{2+}$-ATPases (SERCA-like)

6 likely facilitate transcellular transport of $\mathrm{Ca}^{2+}$ (Figure 5)

7 The coccolithophore cell faces the challenge of maintaining a large trans-

8 cellular flux of $\mathrm{Ca}^{2+}$ from seawater to the coccolith-forming compartment, without

9 disturbing the low cytosolic $\left[\mathrm{Ca}^{2+}\right]$. Likewise a mechanism of removal of $\mathrm{H}^{+}$

10 generated by calcification that avoids catastrophic acidosis of the cytosol is

11 required. The endomembrane pathway and its arrangement with the coccolith-

12 vesicle offer solutions to this problem that also meet some of the necessary charge-

13 balancing (Raven \& Crawfurd 2012) (Figure 5). Moreover, the presence of a closely

14 associated endomembrane system may also explain the paradox presented by

15 biochemical purification of a V-type $\mathrm{H}^{+}$-ATPase from CV-enriched membranes in

16 Pleurochrysis (Corstjens et al. 2001). The orientation of a V-type $\mathrm{H}^{+}$-ATPase is the

17 reverse to that required to remove $\mathrm{H}^{+}$from the $\mathrm{CV}$, but its association with the $\mathrm{CV}$

18 may be due to co-purification of closely associated endomembranes in which a V-

19 type $\mathrm{H}^{+}$-ATPase could act to sequester $\mathrm{H}^{+}$released from the $\mathrm{CV}$ (Figure 5).

20 Based on gene expression studies a model for $\mathrm{Ca}^{2+}$ accumulation has been

21 proposed whereby $\mathrm{Ca}^{2+}$ is concentrated in a $\mathrm{CV}$ precursor compartment prior to

22 delivery to the calcification site (Mackinder et al. 2010, Mackinder et al. 2011).

23 Consistent with this is the recent demonstration of a vacuolar-like compartment in

24 calcifying E. huxleyi cells that concentrates a disordered $\mathrm{Ca}^{2+}$ phase and makes close

25 contact with the CV (Sviben et al. 2016). Some of the features of the precursor

26 vesicles associated with coccolith production are reminiscent of $\mathrm{Ca}^{2+}$ and P-rich

27 acidocalcisomes that have been identified in a variety of microorganisms, including

28 apicomplexan parasites (Rohloff et al. 2011). Whether such a compartment plays a

29 direct role in coccolithophore calcification remains to be determined.

31 8.4. The Problem of Protons 
1 The formation of $\mathrm{CaCO}_{3}$ from $\mathrm{Ca}^{2+}$ and $\mathrm{HCO}_{3}$ - external substrates (Bach et al. 2013)

2 necessitates the production of $\mathrm{H}^{+}$, most likely at the site of $\mathrm{CaCO}_{3}$ precipitation that

3 needs to be removed from the $\mathrm{CV}$ and ultimately the cytosol to prevent acidosis

4 (Brownlee et al. 2015). Evidence from both gene expression studies (Mackinder et

5 al. 2011) and flux modeling (Holtz et al. 2013) is consistent with the operation of

$6 \mathrm{Ca}^{2+} / \mathrm{H}^{+}$antiporters with a stoichiometry of at least $2 \mathrm{H}^{+}: 1 \mathrm{Ca}^{2+}$, together with $\mathrm{V}$-type

$7 \quad \mathrm{H}^{+}$-ATPases in recycling of $\mathrm{H}^{+}$into the endomembrane system and in the

8 accumulation of $\mathrm{Ca}^{2+}$ in a precursor calcification compartment (Brownlee et al.

9 2015, Taylor et al. 2011). The finding that the coccolithophore plasma membrane

10 has a high permeability for $\mathrm{H}^{+}$(Suffrian et al. 2011) due to the activity of voltage-

11 dependent $\mathrm{H}^{+}$channels (Taylor et al. 2011) that activate upon cytosolic acidification

12 and/or depolarization of membrane potential, provides an effective high capacity $\mathrm{H}^{+}$

13 efflux pathway that can alleviate transient imbalances in $\mathrm{H}^{+}$production between

14 calcification and $\mathrm{H}^{+}$consumption though metabolism and buffering. This role for $\mathrm{H}^{+}$

15 channels in cellular $\mathrm{pH}$ homeostasis represents a unique and highly novel aspect of

16 coccolithophore biology.

\subsection{Silicon and new paradigms for calcification}

19 Calcification in the coccolithophores evolved at a time (c. $300 \mathrm{Ma}$ ) when the 20 dissolved Si concentrations (DSi) of the surface ocean were much greater than they

21 are today. The subsequent expansion of the diatoms at the beginning of the Cenozoic

22 (from $66 \mathrm{Ma}$ ) led to a dramatic decline in the concentrations of DSi in the surface

23 ocean (Siever 1992), which in turn resulted in a decrease in extent of silica

24 produced by other silicified organisms, such as the heavily silicified sponges and

25 radiolarians (Lazarus et al. 2009, Maldonado et al. 1999). The ability of diatoms to

26 draw down DSi is due to high-affinity $\mathrm{Na}^{+}$-coupled Si transporters (known as SITs)

27 in their plasma membrane that facilitate uptake of silicic acid against a

28 concentration gradient, leading to its eventual depletion from the surrounding

29 seawater. Until recently, SITs were identified only in stramenopiles (diatoms and

30 chrysophytes) and siliceous choanoflagellates (Marron et al. 2013). However, a SIT

31 homologue was recently described in Prymnesium neolepis, an unusual silicifying 
1 haptophyte (Durak et al. 2016). Remarkably, a SIT was also found in the

2 coccolithophore, Scyphosphaera apsteinii and closely related SIT-like proteins (SITL)

3 were also discovered in three coccolithophore species (S. apsteinii, C. pelagicus and

4 C. leptoporus). Each of these species was shown to be highly sensitive to germanium

5 (Ge), an analogue of Si that acts as competitive inhibitor of Si uptake. Growth of

6 these coccolithophores in low Si seawater amended with $5 \mu \mathrm{M}$ Ge resulted in highly

7 aberrant coccoliths and this inhibitory effect was reversed by the addition of 100

$8 \mu \mathrm{M}$ Si. Prolonged growth at very low $\mathrm{Si}(<0.1 \mu \mathrm{M})$ also resulted in the production of

9 aberrant coccoliths, indicating that $\mathrm{Si}$ is required for calcification. In stark contrast,

10 no inhibitory effects of Ge (up to $20 \mu \mathrm{M}$ ) were observed in E. huxleyi and G. oceanica,

11 bloom forming species that do not possess SITs or SITLs.

12 The role of $\mathrm{Si}$ in coccolithophore calcification remains to be determined.

13 Small amounts of Si can be detected in the coccoliths of S. apsteinii, suggesting that

14 Si may play a direct role in coccolith formation (Drescher et al. 2012). Recent

15 advances have shown that $\mathrm{Si}$ can act to stabilise amorphous $\mathrm{CaCO}_{3}$ (ACC)(Ihli et al.

16 2014, Kellermeier et al. 2010). It is therefore possible that Si stabilises an otherwise

17 labile amorphous $\mathrm{CaCO}_{3}$ phase (ACC) in coccolith development, which can then

18 undergo transition to the crystalline calcite in combination with the coccolith-

19 associated organic components. There is currently no conclusive evidence for the

20 involvement of ACC in coccolithophore calcification, although small $\mathrm{Ca}^{2+}$-rich

21 membrane bound granules known as coccolithosomes appear to be an integral part

22 of calcification at least in the early stages of coccolith production in Hymenomonas

23 carterae and Pleurochrysis carterae. A transition from amorphous ACC present in the

24 CV to calcite at the onset of calcification is difficult to reconcile with the fact that the

25 very first $\mathrm{CaCO}_{3}$ that appears to precipitate onto the baseplate scale is in the form of

26 a highly ordered ring of rhomboid calcite crystallites, the protococcolith ring (Young

27 et al. 1999), although this ontogenetic model coccolith growth is derived from the

28 non-Si requiring E. huxleyi, and it is premature to rule out a contribution of ACC to

29 calcification in all groups. High-resolution analytical measurements of

30 coccolithophore cells and their calcite coccoliths through development, comparing

31 Si-requiring and non-requiring species is now required to determine the mechanism 
1 of Si-regulation of calcification, whether ACC is involved in the process and to what

2 degree $\mathrm{Si}$ is incorporated into the calcite.

3 The long-held concept that the ecological niche of coccolithophores is

4 partially defined by their lack of a requirement for $\mathrm{Si}$ is largely derived from studies

5 on E. huxleyi (Tyrrell \& Merico 2004). The presence of SIT/SITL transporters and

6 Ge-sensitivity in a broader range of coccolithophores indicates there is considerable

7 physiological diversity in their Si requirements. Although the Si quota of

8 coccolithophores is likely to be small, the ability of certain species (i.e. E. huxleyi and

9 G. oceanica) to avoid a requirement for Si entirely may confer a competitive

10 advantage in specific environments, such as in the Si-depleted waters following a

11 diatom bloom. A wider phylogenetic analysis should reveal whether a requirement

12 for $\mathrm{Si}$ is an ancestral trait in coccolithophores and identify whether the dramatic

13 depletion of DSi from surface waters during the Cenozoic provided selective

14 pressure to uncouple calcification from Si in some coccolithophore lineages such as

15 the Noelarhabdaceae. The identification of this major mechanistic difference

16 between ecologically important coccolithophore species again highlights the need to

17 study a multitude of species in laboratory-based studies in order to address how the

18 differing requirements for Si influence competitive interactions of coccolithophores

19 with their ecosystem.

\subsection{Coccolithophore distribution, diversity and adaptation}

Much of our understanding of coccolithophore physiology relates to $E$.

23 huxleyi, although it is becoming clear that other coccolithophore lineages may

24 exhibit considerably different physiological attributes (Durak et al. 2016, Rickaby et

25 al. 2010). Whilst E. huxleyi is the most abundant coccolithophore species in modern

26 oceans, many of the other larger coccolithophores such as Coccolithus pelagicus and

27 Calcidiscus leptoporus contribute significantly to global calcite production (Daniels

28 et al. 2014). Coccolithophore species exhibit distinct vertical and latitudinal

29 zonation (Boeckel \& Baumann 2008, Okada \& Honjo 1973, Winter et al. 1994) with

30 species diversity greatest in the stable, low nutrient environments found at low

31 latitudes. In more variable regimes with higher nutrients found at higher latitudes, 
1 coccolithophore species diversity is lower and assemblages are often dominated by

2 Emiliania (Brun et al. 2015). Vertical zonation is pronounced in the communities

3 found at higher latitudes. For example, in the equatorial Atlantic, the characteristic

4 coccolithophores of the oligotrophic surface waters are Umbellosphaera irregularis

5 and Umbellosphaera tenuis, whereas the typical coccolithophores of the lower photic

6 zone are Florisphaera profunda and Gladiolithus flabellatus (Kinkel et al. 2000).

$7 \quad$ Emiliania is distinct from many other species as it is common in all photic zones. The

8 pronounced vertical zonation of coccolithophore species may be driven by factors

9 such as light, temperature and nutrients, which are all likely to contribute to

10 diversity in coccolithophore physiology. Many coccolithophore species, particularly

11 those from the lower photic zone, have not yet been isolated in laboratory culture

12 and so it is likely that the true breadth of coccolithophore physiology is yet to be

13 discovered.

14 Intra-specific genetic diversity in coccolithophores also contributes to their 15 physiological and morphological diversity. Strains of E. huxleyi can be assigned to a

16 series of different morphotypes, based on the morphology of their coccoliths (Young

17 \& Westbroek 1991). Strain-specific differences in pigments and composition of lipid

18 biomarkers such as alkenones and alkenes have also been observed, although these

19 could not be assigned to different morphotypes (Conte et al. 1995). The sequencing

20 of the E. huxleyi genome revealed pronounced genetic variability between strains,

21 even those that have been isolated from similar geographical locations (Read et al.

22 2013). E. huxleyi strains possess a core genome that is common to all strains, as well

23 as an additional complement of genes that differ markedly between strains. This

24 'pan-genome' is proposed to have enabled physiological plasticity and contributed

25 to the ecological success of E. huxleyi in diverse marine environments (Read et al.

26 2013). Recently, detailed phylogenetic studies have provided insight into potential

27 mechanisms underlying the genetic diversity exhibited by Emiliania. For example,

28 Emiliania shows evidence for introgressive hybridization with older Gephyrocapsa

29 clades, a process that would result in extensive genetic mixing (Bendif et al. 2015).

30 The predicted changes in ocean carbonate chemistry have led to

31 considerable interest in the ability of coccolithophores to adapt to changes in their 
1 environment. A full discussion of the implications of environmental change on

2 coccolithophore biology is beyond the scope of this review (the reader is directed to

3 several excellent recent reviews (Meyer \& Riebesell 2015, Ridgwell et al. 2009, Rost

4 et al. 2008)) but it is important to note the capacity for adaptation when considering

5 genetic and physiological diversity between strains. Recent evidence suggests that

6 the physiological properties of E. huxleyi strains isolated from differing geographical

7 locations relates to the carbonate chemistry of the seawater from which they were

8 isolated (Rickaby et al. 2016). This could reflect the ability of E. huxleyi to adapt to

9 its environment or represent the selection of strains that exhibit a competitive

10 advantage from a standing genetic stock. Laboratory experimental evolution

11 approaches that address this question suggest that both processes are likely to

12 contribute to adaptive evolution within E. huxleyi populations over relevant

13 timescales (Lohbeck et al. 2012).

\section{$15 \quad 11.0$ Concluding remarks}

16 Remarkable new discoveries of cell physiology, microbial interactions, metabolism,

17 and biomineralization continue to emerge. These have important implications for

18 understanding ecosystem linkages and the role coccolithophores play in marine

19 biogeochemical cycles. To date, advances have largely been achieved through a

20 combination of genomics, transcriptomics, proteomics and metabolomics

21 approaches together with targeted functional characterization of specific genes. The

22 rapidly increasing haptophyte and coccolithophore genomic and transcriptomic

23 resources provides unprecedented opportunity to understand the molecular basis

24 of physiological versatility and diversity. The lack of stable transformation and

25 reverse genetic systems is a bottleneck that now limits progress in understanding

26 specific processes such as calcification. A multidisciplinary approach that combines

27 functional characterization of genes with high-resolution ultrastructure, and

28 analytical chemistry promises to yield answers to some of the most pressing

29 questions in coccolithophore calcification.

$30 \quad$ Much of our understanding of coccolithophore biology comes from studies

31 with E. huxleyi, but it is clear there is considerable physiological diversity between 
1 ecologically important coccolithophore species, as well as genetic diversity within

2 species. It is important to understand how these differences influence the

3 distribution and ecological role of coccolithophores. This requires comparative

4 physiology, ecology and genomics of a broader range of coccolithophore species

5 representing the four major families.

6 With a better understanding of the unique physiology of coccolithophores it

$7 \quad$ will be possible to provide inputs compatible with trait-based ecosystem models

8 that have great potential for describing biogeography of phytoplankton and their

9 responses to environmental variables (Follows \& Dutkiewicz 2011). The future is

10 promising with the community increasingly adopting an interdisciplinary approach

11 from bench to field in order to understand how the unique physiological versatility

12 and metabolic repertoire of coccolithophores defines their ecology and responses to

13 climate change.

\section{Author financial interests:}

16 The authors have no competing or financial interests related to the publication of

17 this article.

\section{Acknowledgments}

20 ART Acknowledges National Science Foundation (grants IOS 0949744 and OCE

21 1638838), Natural Environmental Research Council UK, University of North

22 Carolina Wilmington College of Arts and Sciences and The Whitely Center at Friday

23 Harbor Laboratories. CB and GW are supported by grants from Natural

24 Environmental Research Council and the European Research Council. 


\section{$1 \quad$ Figures}

\section{Figure 1. Coccolithophores and intracellular calcification}

3 (a) Scanning electron micrographs of several coccolithophores reproduced to the

4 same scale. From left to right: Scyphosphaera apsteinii, Emiliania huxleyi, Calcidiscus

5 leptoporus, Gephyrocapsa oceanica and Coccolithus braarudii. (b-c) Model illustrating

6 the sequence of intracellular coccolith production. (b) The process starts with

7 nucleation of peripheral calcite crystals onto the organic baseplate that is produced

8 in a Golgi-derived coccolith vesicle. Trans-Golgi vesicle trafficking provides organic

9 components. (c) As the calcite coccolith matures the endomembranes associated

10 with the CV become more complex, likely playing an important role in ion transport

11 and coccolith morphology. (d) Coccoliths are released to the cell surface through

12 exocytosis. Recycling of the membrane components is likely required for new

13 coccolith production.

15 Figure 2. Coccolithophore life cycle transitions; environmental factors and 16 niche partitioning.

17 A cartoon summarizing the major abiotic and biotic factors that appear to influence

18 life cycle phase transitions in coccolithophores. See section 3.0 for details.

20 Figure 3. Microbial interactions with coccolithophores and DMSP metabolism

21 Summary of recent findings related to bacterial and virus interactions with

22 Emiliania huxleyi. These interactions also intersect with the DMSP metabolism of

23 coccolithophores. Aside from its osmoprotective properties, DMSP serves other

24 functional roles. These include anti-grazing activity, antioxidant capacity and

25 sustaining bacterial mutualisms. The recently discovered DMSP-lyase Alma1 in $E$.

26 huxleyi indicates endogenous control of DMSP pools can be dynamically regulated in

27 coccolithophores. Release of DMSP on cell death leads to rapid turnover and

28 increased DMS production through bacteria-mediated cleavage. See section 4.2 and

295.2 for details.

31 Figure 4. E. huxleyi virus dynamics; a timeline of major cellular events 
1 A diagram that summarizes recent research findings on the cellular dynamics of EhV

2 infection of diploid E. huxleyi. Upper panel shows main stages of infection of $E$.

3 huxleyi by viral particles in the ocean, and indicates the potential of viral

4 transmission mechanisms that have been identified. The lower panel indicates a

5 timeline of hours post infection (hpi) and the main cellular events that have been

6 examined in laboratory cultures of E. huxleyi. See section 4.2 for details.

8 Figure 5. Ion transport during calcification in coccolithophores

9 A cartoon illustrating how the ion transport mechanisms, known to be related to

10 calcification, may be integrated in this process. Of particular importance is the

11 efficient movement of $\mathrm{Ca}^{2+}$ and $\mathrm{H}^{+}$without compromising cytoplasmic homeostasis

12 of these ions. The endomembrane system that surrounds the coccolith vesicle likely

13 plays a critical role. The role of $S i$ in coccolith production has yet to be determined,

14 but may be important in stabilizing an intermediate form of $\mathrm{CaCO}_{3}$. See Section 8.3

15 for details.

16 
1 Figure 1 Coccolithophores and intracellular calcification
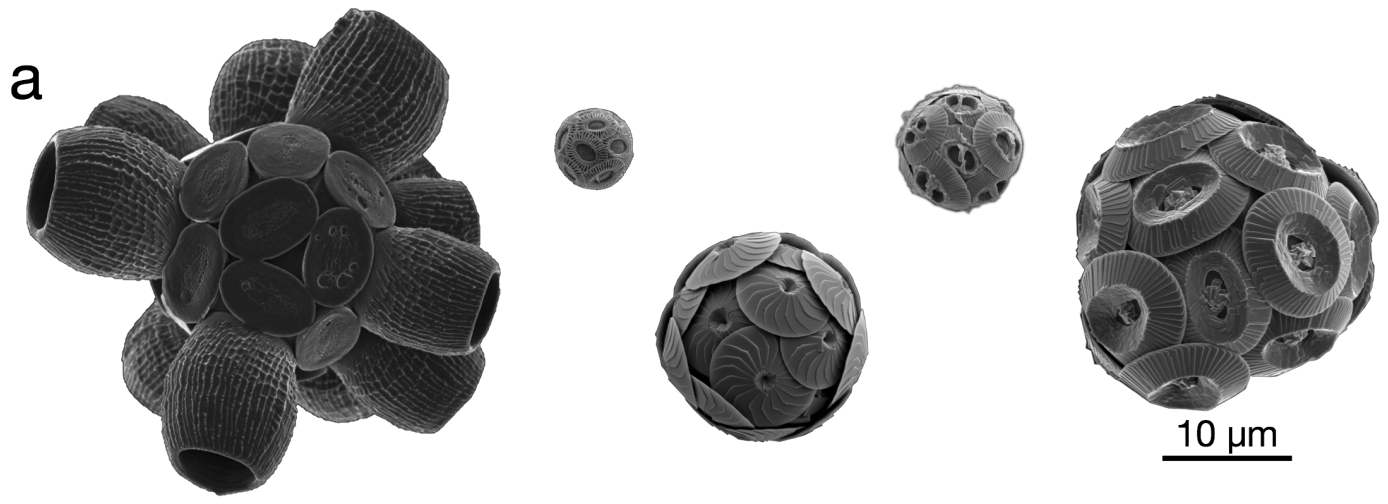

$10 \mu \mathrm{m}$

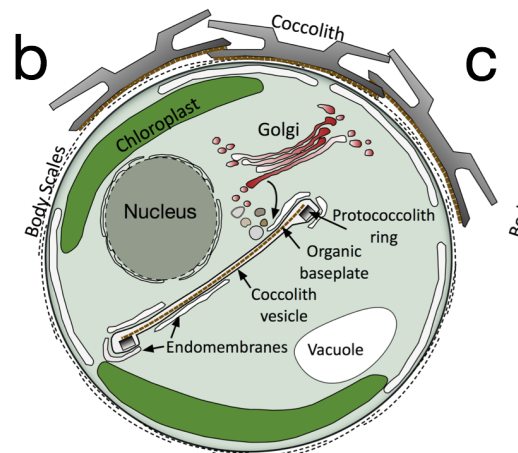

Nucleation
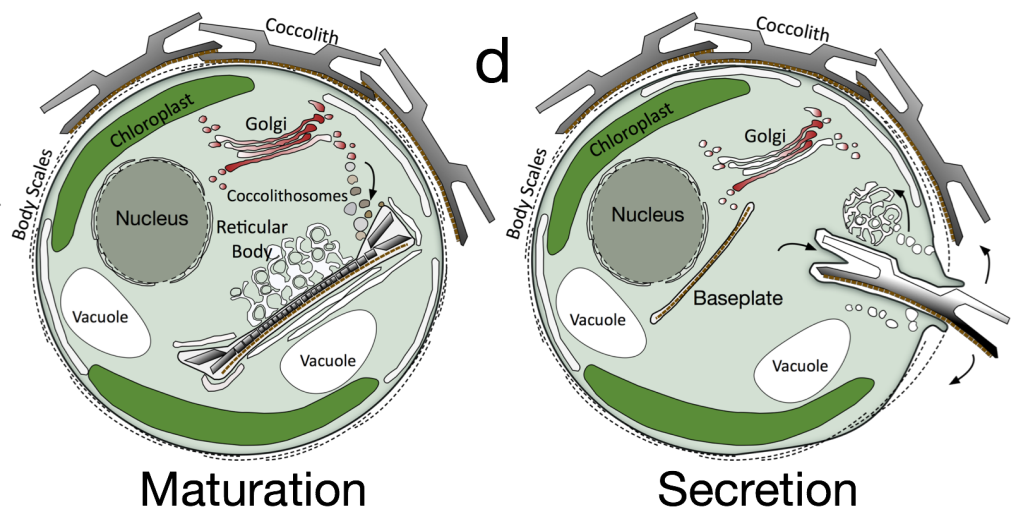

3

4 
1 Figure 2. Life cycle transitions- environmental factors and niche partitioning

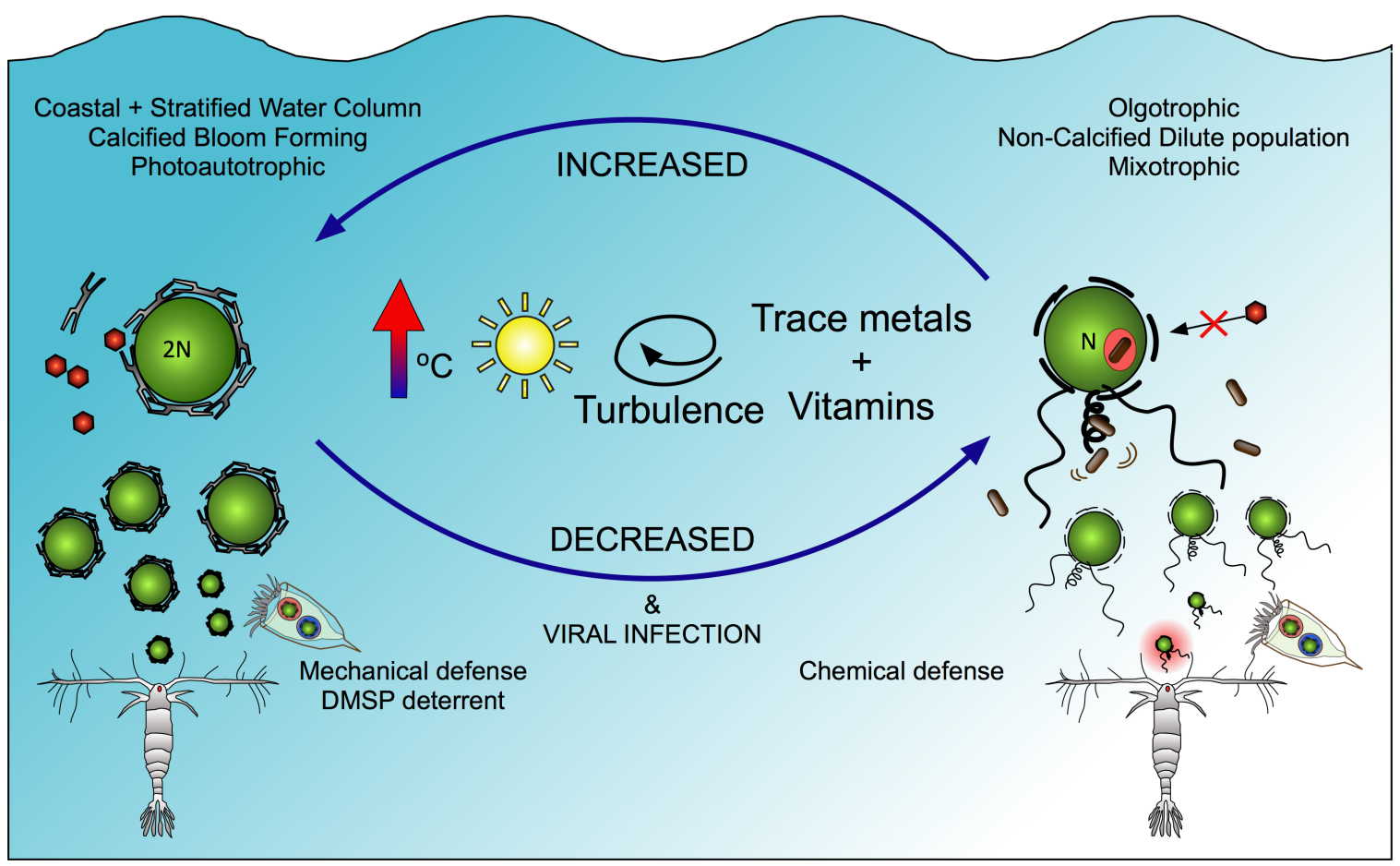


1 Figure 3. Microbial interactions and DMSP metabolism

\section{Mutualist}

(Growth enhancers

\& antibiotics)

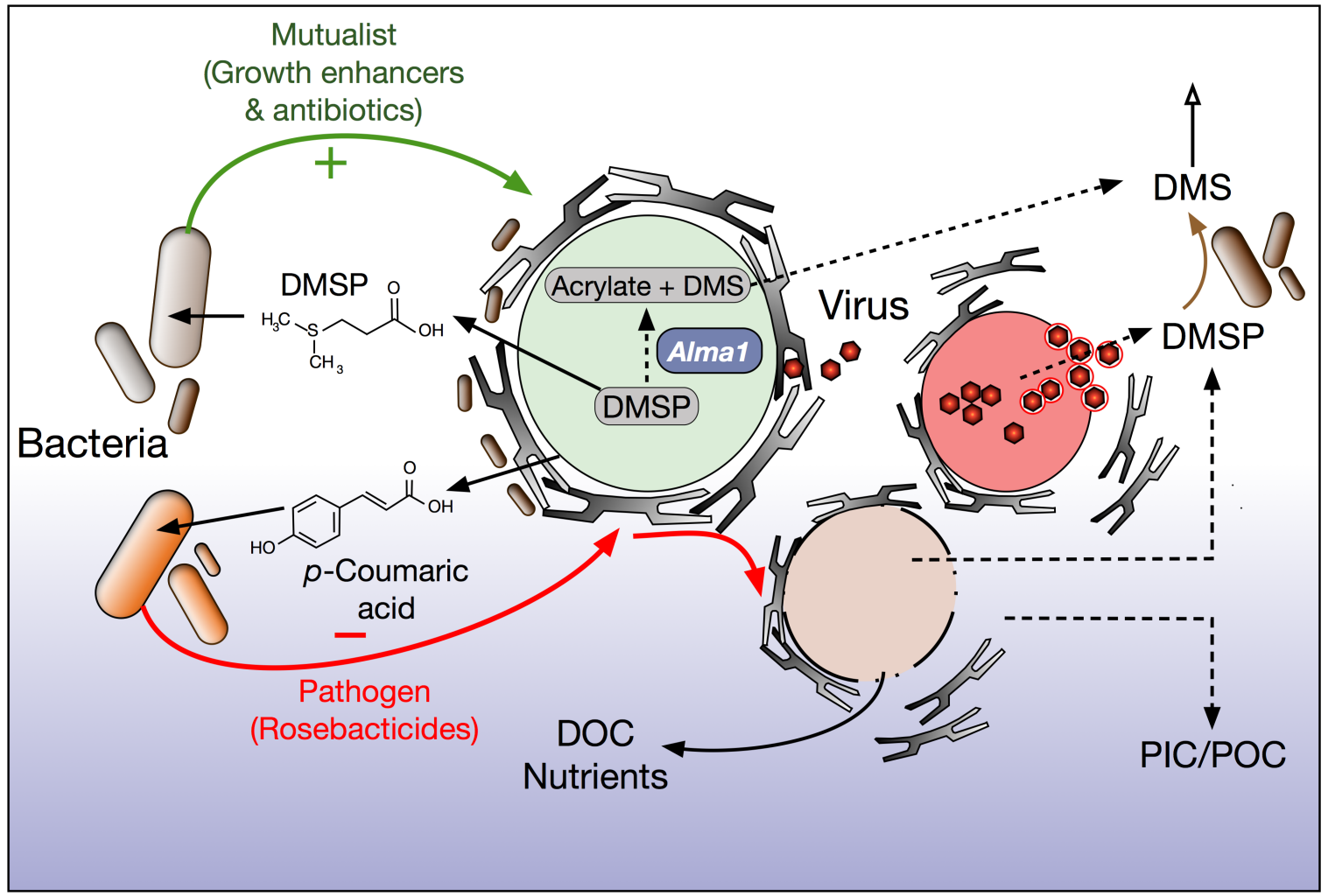


1 Figure 4 E. huxleyi virus; timeline of major cellular events.

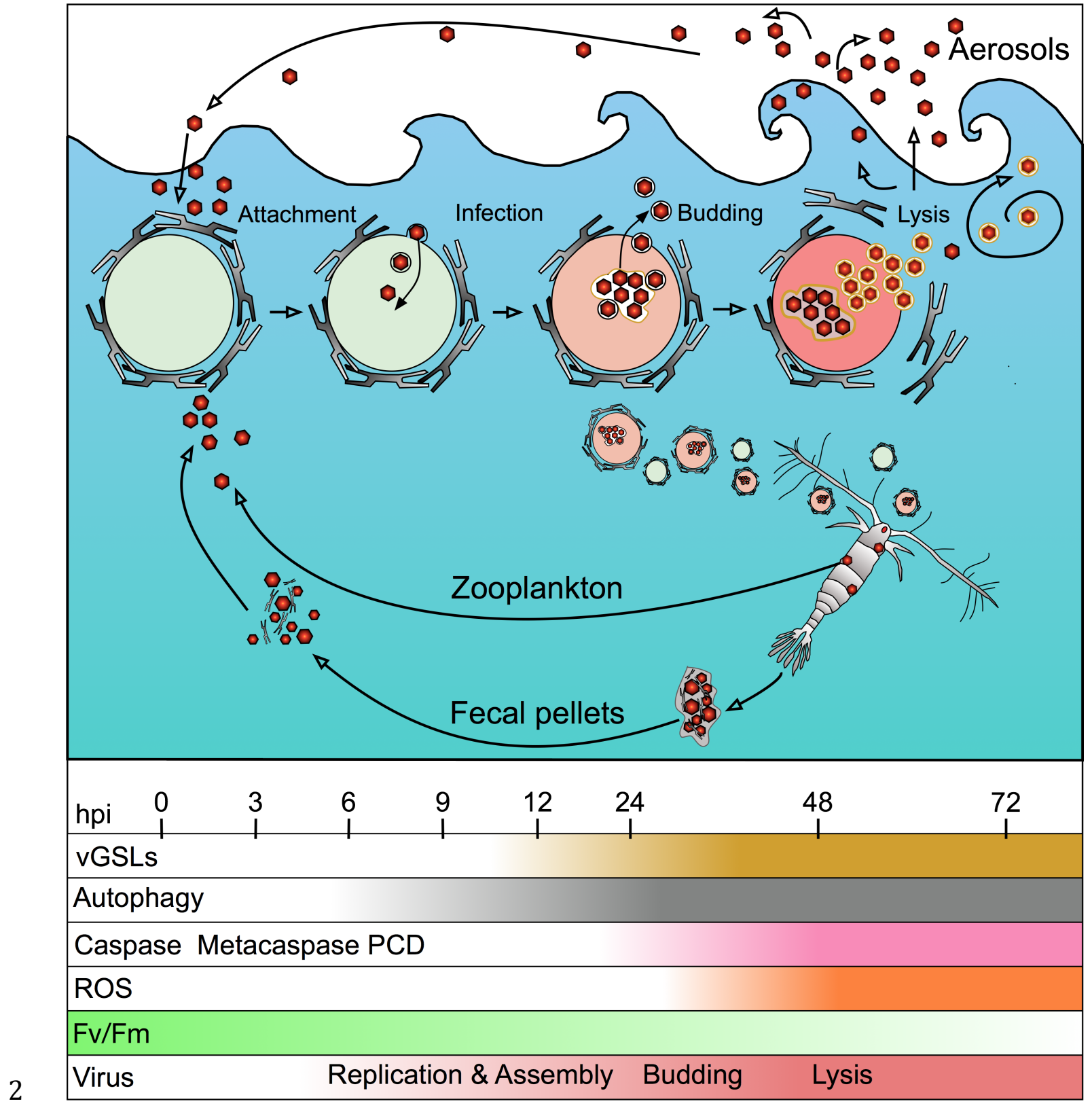


1 Figure 5 Ion transport during calcification in coccolithophore

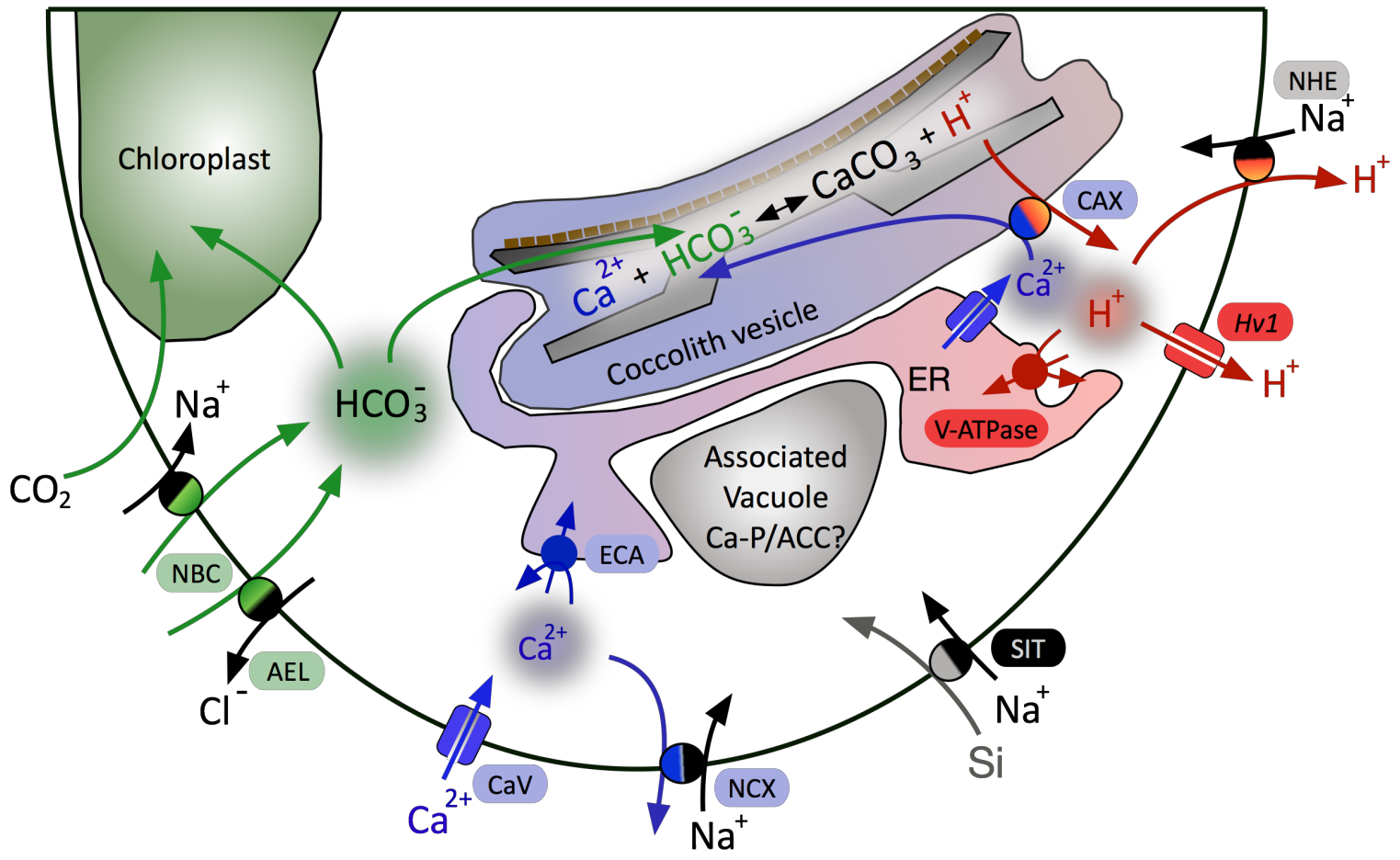


References

Alcolombri U, Ben-Dor S, Feldmesser E, Levin Y, Tawfik DS, Vardi A. 2015. Identification of the algal dimethyl sulfide-releasing enzyme: A missing link in the marine sulfur cycle. Science 348: 1466-69

Bach LT, Mackinder LCM, Schulz KG, Wheeler G, Schroeder DC, et al. 2013. Dissecting the impact of $\mathrm{CO}_{2}$ and $\mathrm{pH}$ on the mechanisms of photosynthesis and calcification in the coccolithophore Emiliania huxleyi. New. Phytol. 199: 121-34

Balch W, Drapeau D, Bowler B, Booth E. 2007. Prediction of pelagic calcification rates using satellite measurements. Deep-Sea Res. Pt. II 54: 478-95

Bartal R, Shi BY, Cochlan WP, Carpenter EJ. 2015. A model system elucidating calcification functions in the prymnesiophyte Emiliania huxleyi reveals dependence of nitrate acquisition on coccoliths. Limnol. Oceanogr. 60: 149-58

Bendif E, Probert I, Young JR, von Dassow P. 2015. Morphological and phylogenetic characterization of new Gephyrocapsa isolates suggests introgressive hybridization in the Emiliania/Gephyrocapsa complex (Haptophyta). Protist 166: 323-36

Berry L, Taylor AR, Lucken U, Ryan KP, Brownlee C. 2002. Calcification and inorganic carbon acquisition in coccolithophores. Funct. Plant. Biol. 29: 28999

Bidle KD, Haramaty L, Barcelos ERJ, Falkowski P. 2007. Viral activation and recruitment of metacaspases in the unicellular coccolithophore, Emiliania huxleyi. Proc. Natl. Acad. Sci. USA 104: 6049-54

Boeckel B, Baumann K-H. 2008. Vertical and lateral variations in coccolithophore community structure across the subtropical frontal zone in the South Atlantic Ocean. Mar. Micropaleont. 67: 255-73

Borman AH, Dejong EW, Huizinga M, Kok DJ, Westbroek P, Bosch L. 1982. The role in $\mathrm{CaCO}_{3}$ crystallization of an acid $\mathrm{Ca}^{2+}$-binding polysaccharide associated with coccoliths of Emiliania huxleyi. Eur. J. Biochem. 129: 179-83

Brownlee C, Taylor AR. 2004. Calcification in coccolithophores: A cellular perspective In Coccolithophores: From molecular processes to global impact, ed. HR Thierstein, JR Young, pp. 31-49. Berlin: Springer

Brownlee C, Wheeler GL, Taylor AR. 2015. Coccolithophore biomineralization: New questions, new answers. Semin. Cell Dev. Biol. 46: 11-16

Brun P, Vogt M, Payne MR, Gruber N, O'Brien CJ, et al. 2015. Ecological niches of open ocean phytoplankton taxa. Limnol. Oceanogr. 60: 1020-38

Burki F, Kaplan M, Tikhonenkov DV, Zlatogursky V, Minh BQ, et al. 2016. Untangling the early diversification of eukaryotes: A phylogenomic study of the evolutionary origins of Centrohelida, Haptophyta and Cryptista. P Roy Soc B Biol Sci 28320152802

Chow JS, Lee C, Engel A. 2015. The influence of extracellular polysaccharides, growth rate, and free coccoliths on the coagulation efficiency of Emiliania huxleyi. Mar. Chem. 175: 5-17 
1 Conte MH, Thompson A, Eglinton G, Green JC. 1995. Lipid biomarker diversity in the coccolithophorid Emiliania huxleyi (Prymnesiophyceae) and related species Gephyrocapsa oceanica J. Phycol. 31: 272-82

Cooper MB, Smith AG. 2015. Exploring mutualistic interactions between microalgae and bacteria in the omics age. Curr. Opin. Plant. Biol. 26: 147-53

Corstjens P, Araki Y, Gonzalez EL. 2001. A coccolithophorid calcifying vesicle with a vacuolar-type ATPase proton pump: Cloning and immunolocalization of the V-0 subunit c(1). J. Phycol. 37: 71-78

Corstjens P, van der Kooij A, Linschooten C, Brouwers GJ, Westbroek P, de Vrind-de Jong EW. 1998. GPA, a calcium-binding protein in the coccolithophorid Emiliania huxleyi (Prymnesiophyceae). J. Phycol. 34: 622-30

Cros L, Estrada M. 2013. Holo-heterococcolithophore life cycles: ecological implications. Mar. Ecol. Prog. Ser. 492: 57-68

Cros L, Kleijne A, Zeltner A, Billard C, Young JR. 2000. New examples of holococcolith-heterococcolith combination coccospheres and their implications for coccolithophorid biology. Mar. Micropaleont. 39: 1-34

Daniels CJ, Sheward RM, Poulton AJ. 2014. Biogeochemical implications of comparative growth rates of Emiliania huxleyi and Coccolithus species. Biogeosciences 11: 6915-25

Danne JC, Gornik SG, Macrae JI, McConville MJ, Waller RF. 2013. Alveolate mitochondrial metabolic evolution: dinoflagellates force reassessment of the role of parasitism as a driver of change in apicomplexans. Mol Biol Evol 30: 123-39

Darroch LJ, Lavoie M, Levasseur M, Laurion I, Sunda WG, et al. 2015. Effect of shortterm light- and UV-stress on DMSP, DMS, and DMSP lyase activity in Emiliania huxleyi. Aquat. Microb. Ecol. 74: 173-85

de Nooijer LJ, Spero HJ, Erez J, Bijma J, Reichart GJ. 2014. Biomineralization in perforate foraminifera. Earth-Science Reviews 135: 48-58

De Vargas C, Aubry M-P, Probert I, Young JR. 2007. Origin and evolution of coccolithophores: From coastal hunters to oceanic farmers In The Evolution of Aquatic Photoautotrophs, ed. PG Falkowski, AH Knoll, pp. 456. New York: Academic Press

Drescher B, Dillaman RM, Taylor AR. 2012. Calcification in the coccolithophore Schyphosphera apsteinii (Prymnesiophycae). J. Phycol. 48: 1343-61

Durak GM, Taylor AR, Walker CE, Probert I, de Vargas C, et al. 2016. A role for diatom-like silicon transporters in calcifying coccolithophores. Nat. Commun. 7: 10543

Evans C, Malin G, Mills GP, Wilson WH. 2006. Viral infection of Emiliania huxleyi (Prymnesiophyceae) leads to elevated production of reactive oxygen species. J. Phycol. 42: 1040-47

Fichtinger-Schepman AMJ, Kamperling JP, Versluis C, Vliegenthart JFG. 1981. Structural studies of the methylated, acid polysaccarides associated with coccoliths of Emiliania huxleyi (Lohmann) Kamptner. Carbohy. Res. 93: 10523

Follows MJ, Dutkiewicz S. 2011. Modeling diverse communities of marine microbes. Ann. Rev. Mar. Sci. 3: 427-51 
Frada M, Percopo I, Young J, Zingone A, de Vargas C, Probert I. 2009. First observations of heterococcolithophore-holococcolithophore life cycle combinations in the family Pontosphaeraceae (Calcihaptophycideae, Haptophyta). Mar. Micropaleont. 71: 20-27

Frada M, Probert I, Allen MJ, Wilson WH, de Vargas C. 2008. The "Cheshire Cat" escape strategy of the coccolithophore Emiliania huxleyi in response to viral infection. Proc. Natl. Acad. Sci. USA 105: 15944-9

Frada MJ, Bidle KD, Probert I, de Vargas C. 2012. In situ survey of life cycle phases of the coccolithophore Emiliania huxleyi (Haptophyta). Environ. Microbiol. 14: 1558-69

Frada MJ, Vardi A. 2015. Algal viruses hitchhiking on zooplankton across phytoplankton blooms. Commun. Integr. Biol. 8: e1029210

Franklin DJ, Steinke M, Young J, Probert I, Malin G. 2010. Dimethylsulphoniopropionate (DMSP), DMSP-lyase activity (DLA) and dimethylsulphide (DMS) in 10 species of coccolithophore. Mar. Ecol. Prog. Ser. 410: 13-23

Fredrickson KA, Strom SL. 2009. The algal osmolyte DMSP as a microzooplankton grazing deterrent in laboratory and field studies. J. Plankton. Res. 31: 135-52

Fresnel J. 1994. A heteromorphic life cycle in two coastal coccolithophorids, Hymenomonas lacuna and Hymenomonas coronata (Prymnesiophyceae). Can. J. Bot. 72: 1455-62

Fulton JM, Fredricks HF, Bidle KD, Vardi A, Kendrick BJ, et al. 2014. Novel molecular determinants of viral susceptibility and resistance in the lipidome of Emiliania huxleyi. Environ. Microbiol. 16: 1137-49

Garren M, Son K, Raina JB, Rusconi R, Menolascina F, et al. 2014. A bacterial pathogen uses dimethylsulfoniopropionate as a cue to target heat-stressed corals. ISME J. 8: 999-1007

Gebser B, Pohnert G. 2013. Synchronized regulation of different zwitterionic metabolites in the osmoadaption of phytoplankton. Mar. Drugs 11: 2168-82

Geisen M, Billard C, Broerse A, Cros L, Probert I, Young J. 2002. Life-cycle associations involving pairs of holococcolithophorid species: intraspecific variation or cryptic speciation? Eur. J. Phycol. 37: 531-50

Green DH, Echavarri-Bravo V, Brennan D, Hart MC. 2015. Bacterial diversity associated with the coccolithophorid algae Emiliania huxleyi and Coccolithus pelagicus f. braarudii. Biomed Res Int

Hagino K, Tomioka N, Young JR, Takano Y, Onuma R, Horiguchi T. 2016. Extracellular calcification of Braarudosphaera bigelowii deduced from electron microscopic observations of cell surface structure and elemental composition of pentaliths. Mar. Micropaleont. 125: 85-94

Harris RP. 1994. Zooplankton grazing on the coccolithophore Emiliania huxleyi and its role in inorganic carbon flux. Mar. Biol. 119: 431-39

Hartmann M, Grob C, Tarran GA, Martin AP, Burkill PH, et al. 2012. Mixotrophic basis of Atlantic oligotrophic ecosystems. Proc. Natl. Acad. Sci. USA 109: 5756-60 
Harvey EL, Bidle KD, Johnson MD. 2015. Consequences of strain variability and calcification in Emiliania huxleyi on microzooplankton grazing. J. Plankton. Res. 37: 1137-48

Harvey EL, Deering RW, Rowley DC, El Gamal A, Schorn M, et al. 2016. A bacterial quorum-sensing precursor induces mortality in the marine coccolithophore, Emiliania huxleyi. Front. Microbiol. 7: 59

Hassenkam T, Johnsson A, Bechgaard K, Stipp SLS. 2011. Tracking single coccolith dissolution with picogram resolution and implications for $\mathrm{CO}_{2}$ sequestration and ocean acidification. Proc. Natl. Acad. Sci. USA 108: 8571-76

Henriksen K, Stipp SLS. 2009. Controlling biomineralization: The effect of solution composition on coccolith polysaccharide functionality. Cryst. Growth Des. 9: 2088-97

Henriksen K, Stipp SLS, Young JR, Marsh ME. 2004. Biological control on calcite crystallization: AFM investigation of coccolith polysaccharide function. Am Mineral 89: 1709-16

Herfort L, Loste E, Meldrum F, Thake B. 2004. Structural and physiological effects of calcium and magnesium in Emiliania huxleyi (Lohmann) Hay and Mohler. J. Struct. Biol. 148: 307-14

Hermoso M. 2014. Coccolith-derived isotopic proxies in palaeoceanography: where geologists need biologists. Cryptogamie Algol. 35: 323-51

Hirokawa Y, Fujiwara S, Tsuzuki M. 2005. Three types of acidic polysaccharides associated with coccolith of Pleurochrysis haptonemofera: comparison with Pleurochrysis carterae and analysis using fluorescein-isothiocyanate-labeled lectins. Mar. Biotech. 7: 634-44

Holtz L-M, Thoms S, Langer G, Wolf-Gladrow DA. 2013. Substrate supply for calcite precipitation in Emiliania huxleyi: assessment of different model approaches. J. Phycol. 49: 417-26

Houdan A, Billard C, Marie D, Not F, Sáez AG, et al. 2004. Holococcolithophore heterococcolithophore (Haptophyta) life cycles: Flow cytometric analysis of relative ploidy levels. Syst. Biodivers. 1: 453-65

Houdan A, Probert I, Van Lenning K, Lefebvre S. 2005. Comparison of photosynthetic responses in diploid and haploid life-cycle phases of Emiliania huxleyi (Prymnesiophyceae). Mar. Ecol. Prog. Ser. 292: 139-46

Houdan A, Probert I, Zatylny C, Veron B, Billard C. 2006. Ecology of oceanic coccolithophores. I. Nutritional preferences of the two stages in the life cycle of Coccolithus braarudii and Calcidiscus leptoporus. Aquat. Microb. Ecol. 44: 291-301

Hunter JE, Frada MJ, Fredricks HF, Vardi A, Van Mooy BAS. 2015. Targeted and untargeted lipidomics of Emiliania huxleyi viral infection and life cycle phases highlights molecular biomarkers of infection, susceptibility, and ploidy. Front. Mar. Sci. 2

Ihli J, Wong WC, Noel EH, Kim YY, Kulak AN, et al. 2014. Dehydration and crystallization of amorphous calcium carbonate in solution and in air. Nat. Commun. 5: 3169 
Kayano K, Saruwatari K, Kogure T, Shiraiwa Y. 2011. Effect of coccolith polysaccharides isolated from the coccolithophorid, Emiliania huxleyi, on calcite crystal formation in in vitro $\mathrm{CaCO}_{3}$ crystallization. Mar. Biotech. 13: 83-92

Kayano K, Shiraiwa Y. 2009. Physiological regulation of coccolith polysaccharide production by phosphate availability in the coccolithophorid Emiliania huxleyi. Plant Cell Physiol. 50: 1522-31

Keller MD, Kiene RP, Matrai PA, Bellows WK. 1999. Production of glycine betaine and dimethylsulfoniopropionate in marine phytoplankton. II. N-limited chemostat cultures. Mar. Biol. 135: 249-57

Kellermeier M, Melero-Garc'ia E, Glaab F, Klein R, Drechsler M, et al. 2010. Stabilization of amorphous calcium carbonate in inorganic silica-rich environments. J. Am. Chem. Soc. 132: 17859-66

Kinkel H, Baumann KH, Cepek M. 2000. Coccolithophores in the equatorial Atlantic Ocean: response to seasonal and Late Quaternary surface water variability. Mar. Micropaleont. 39: 87-112

Kobayashi Y, Torii A, Kato M, Adachi K. 2007. Accumulation of cyclitols functioning as compatible solutes in the haptophyte alga Pavlova sp. Phycol. Res. 55: 8190

Kolb A, Strom S. 2013. An inducible antipredatory defense in haploid cells of the marine microalga Emiliania huxleyi (Prymnesiophyceae). Limnol. Oceanogr. 58: $932-44$

Langer G, de Nooijer LJ, Oetjen K. 2010. On the role of the cytoskeleton in coccolith morphogenesis: The effect of cytoskeleton inhibitors. J. Phycol. 46: 1252-56

Langer G, Gussone N, Nehrke G, Riebesell U, Eisenhauer A, et al. 2006. Coccolith strontium to calcium ratios in Emiliania huxleyi: The dependence on seawater strontium and calcium concentrations. Limnol. Oceanogr. 51: 31020

Lazarus DB, Kotrc B, Wulf G, Schmidt DN. 2009. Radiolarians decreased silicification as an evolutionary response to reduced Cenozoic ocean silica availability. Proc. Natl. Acad. Sci. USA 106: 9333-38

Lee LJY, Klute MJ, Herman EK, Read B, Dacks JB. 2015. Losses, expansions, and novel subunit discovery of adaptor protein complexes in haptophyte algae. Protist 166: 585-97

Lehahn Y, Koren I, Schatz D, Frada M, Sheyn U, et al. 2014. Decoupling physical from biological processes to assess the impact of viruses on a mesoscale algal bloom. Curr. Biol. 24: 2041-46

Leonardos N, Read B, Thake B, Young JR. 2009. No mechanistic dependence of photosynthesis on calcification in the coccolithophorid Emiliania huxleyi (Haptophyta). J. Phycol. 45: 1046-51

Levin LA, Honisch B, Frieder CA. 2015. Geochemical proxies for estimating faunal exposure to ocean acidification. Oceanography 28: 62-73

Liu H, Aris-Brosou S, Probert I, de Vargas C. 2010. A time line of the environmental genetics of the haptophytes. Mol. Biol. Evol. 27: 161-76

Lohbeck KT, Reibesell U, Reusch TBH. 2012. Adaptive evolution of a key phytoplankton species to ocean acidification. Nat. Geosci. 5: 346-51 
Mackinder L, Wheeler G, Schroeder D, Riebesell U, Brownlee C. 2010. Molecular mechanisms underlying calcification in coccolithophores. Geomicrobiol. J. 27: 585-95

Mackinder L, Wheeler G, Schroeder D, von Dassow P, Riebesell U, Brownlee C. 2011. Expression of biomineralization-related ion transport genes in Emiliania huxleyi. Environ. Microbiol. 13: 3250-65

Mackinder LC, Worthy CA, Biggi G, Hall M, Ryan KP, et al. 2009. A unicellular algal virus, Emiliania huxleyi virus 86, exploits an animal-like infection strategy. J. Gen. Virol. 90: 2306-16

Maldonado M, Carmona MG, Uriz MJ, Cruzado A. 1999. Decline in Mesozoic reefbuilding sponges explained by silicon limitation. Nature 401: 785-88

Malitsky S, Ziv C, Rosenwasser S, Zheng S, Schatz D, et al. 2016. Viral infection of the marine alga Emiliania huxleyi triggers lipidome remodeling and induces the production of highly saturated triacylglycerol. New. Phytol. 210: 88-96

Marron AO, Alston MJ, Heavens D, Akam M, Caccamo M, et al. 2013. A family of diatom-like silicon transporters in the siliceous loricate choanoflagellates. $P$ Roy Soc B Biol Sci 280: 20122543

Marsh ME. 1994. Polyanion-mediated mineralization - Assembly and reorganization of acidic polysaccharides in the Golgi system of a coccolithophorid alga during mineral deposition. Protoplasma 177: 108-22

Marsh ME, Chang DK, King GC. 1992. Isolation and characterization of a novel acidic polysaccharide containing tartrate and glyoxylate residues from the mineralized scales of a unicellular coccolithophorid alga Pleurochrysis carterae. J. Biol. Chem. 267: 20507-12

Marsh ME, Ridall AL, Azadi P, Duke PJ. 2002. Galacturonomannan and Golgi-derived membrane linked to growth and shaping of biogenic calcite. J. Struct. Biol. 139: 39-45

McKew BA, Davey P, Finch SJ, Hopkins J, Lefebvre SC, et al. 2013a. The trade-off between the light-harvesting and photoprotective functions of fucoxanthinchlorophyll proteins dominates light acclimation in Emiliania huxleyi (clone CCMP 1516). New. Phytol. 200: 74-85

McKew BA, Lefebvre SC, Achterberg EP, Metodieva G, Raines CA, et al. 2013b. Plasticity in the proteome of Emiliania huxleyi CCMP 1516 to extremes of light is highly targeted. New. Phytol. 200: 61-73

Mckew BA, Metodieva G, Raines CA, Metodiev MV, Geider RJ. 2015. Acclimation of Emiliania huxleyi (1516) to nutrient limitation involves precise modification of the proteome to scavenge alternative sources of $\mathrm{N}$ and P. Environ. Microbiol. 17: 4050-62

Meyer J, Riebesell U. 2015. Reviews and syntheses: Responses of coccolithophores to ocean acidification: a meta-analysis. Biogeosciences 12: 1671-82

Mitchell JG, Seuront L, Doubell MJ, Losic D, Voelcker NH, et al. 2013. The role of diatom nanostructures in biasing diffusion to improve uptake in a patchy nutrient environment. PLoS One 8: e59548

Mitra A, Flynn KJ, Burkholder JM, Berge T, Calbet A, et al. 2014. The role of mixotrophic protists in the biological carbon pump. Biogeosciences 11: 9951005 
Mizukawa Y, Miyashita Y, Satoh M, Shiraiwa Y, Iwasaka M. 2015. Light intensity modulation by coccoliths of Emiliania huxleyi as a micro-photo-regulator. Sci. Rep. 5

Monier A, Pagarete A, de Vargas C, Allen MJ, Read B, et al. 2009. Horizontal gene transfer of an entire metabolic pathway between a eukaryotic alga and its DNA virus. Genome Res. 19: 1441-9

Moran MA, Reisch CR, Kiene RP, Whitman WB. 2012. Genomic Insights into Bacterial DMSP Transformations. Ann. Rev. Mar. Sci. 4: 523-42

Muller MN, Ramos JBE, Schulz KG, Riebesell U, Kazmierczak J, et al. 2015. Phytoplankton calcification as an effective mechanism to alleviate cellular calcium poisoning. Biogeosciences 12: 6493-501

Nanninga HJ, Tyrrell T. 1996. Importance of light for the formation of algal blooms by Emiliania huxleyi. Mar. Ecol. Prog. Ser. 136: 195-203

Nöel M-H, Kawachi M, Inouye I. 2004. Induced dimorphic life cycle of a coccolithophorid, Calyptrosphaera sphaeroidea (Prymnesiophyceae, Haptophyta). J. Phycol. 40: 112-29

O’Brien CJ, Vogt M, Gruber N. 2016. Global coccolithophore diversity: Drivers and future change. Prog. Oceanogr. 140: 27-42

Obata T, Schoenefeld S, Krahnert I, Bergmann S, Scheffel A, Fernie AR. 2013. Gaschromatography mass-spectrometry (GC-MS) based metabolite profiling reveals mannitol as a major storage carbohydrate in the coccolithophorid alga Emiliania huxleyi. Metabolites 3: 168-84

Okada H, Honjo S. 1973. Distribution of oceanic coccolithophorids in the Pacific. Deep-Sea Research 20: 355-64

Okumura T, Suzuki M, Nagasawa H, Kogure T. 2012. Microstructural variation of biogenic calcite with intracrystalline organic macromolecules. Cryst. Growth Des. 12: 224-30

Oviedo A, Ziveri P, Alvarez M, Tanhua T. 2015. Is coccolithophore distribution in the Mediterranean Sea related to seawater carbonate chemistry? Ocean Sci. 11: 13-32

Ozaki N, Sakuda S, Nagasawa H. 2007. A novel highly acidic polysaccharide with inhibitory activity on calcification from the calcified scale "coccolith" of a coccolithophorid alga, Pleurochrysis haptonemofera. Biochem. Biophys. Res. Commun. 357: 1172-6

Paasche E. 1968. Biology and Physiology of Coccolithophorids. Ann. Rev. Microbiol. 22: 71-86

Paasche E. 2001. A review of the coccolithophorid Emiliania huxleyi (Prymnesiophyceae), with particular reference to growth, coccolith formation, and calcification-photosynthesis interactions. Phycologia 40: 50329

Pagarete A, Le Corguille G, Tiwari B, Ogata H, de Vargas C, et al. 2011. Unveiling the transcriptional features associated with coccolithovirus infection of natural Emiliania huxleyi blooms. FEMS Microbiol. Ecol. 78: 555-64

Quinn PS, Cortes MY, Bollmann J. 2005. Morphological variation in the deep oceandwelling coccolithophore Florisphaera profunda (Haptophyta). Eur. J. Phycol. 40: $123-33$ 
Ramos JBE, Schulz KG, Febiri S, Riebesell U. 2012. Photoacclimation to abrupt changes in light intensity by Phaeodactylum tricornutum and Emiliania huxleyi: the role of calcification. Mar. Ecol. Prog. Ser. 452: 11-26

Raven JA, Crawfurd K. 2012. Environmental controls on coccolithophore calcification. Mar. Ecol. Prog. Ser. 470: 137-66

Raven JA, Giordano M. 2009. Biomineralization by photosynthetic organisms: evidence of coevolution of the organisms and their environment? Geobiology 7: $140-54$

Read BA, Kegel J, Klute MJ, Kuo A, Lefebvre SC, et al. 2013. Pan genome of the phytoplankton Emiliania underpins its global distribution. Nature 499: 20913

Rickaby R, Hermoso M, Lee R, Rae B, Heureux A, et al. 2016. Environmental carbonate chemistry selects for phenotype of recently isolated strains of Emiliania huxleyi. Deep Sea Research in press

Rickaby REM, Henderiks J, Young JN. 2010. Perturbing phytoplankton: response and isotopic fractionation with changing carbonate chemistry in two coccolithophore species. Clim. Past 6: 771-85

Ridgwell A, Schmidt DN, Turley C, Brownlee C, Maldonado MT, et al. 2009. From laboratory manipulations to Earth system models: scaling calcification impacts of ocean acidification. Biogeosciences 6: 2611-23

Rohloff P, Miranda K, Rodrigues JC, Fang J, Galizzi M, et al. 2011. Calcium uptake and proton transport by acidocalcisomes of Toxoplasma gondii. PLoS One 6: e18390

Rokitta SD, de Nooijer LJ, Trimborn S, de Vargas C, Rost B, John U. 2011. Transcriptome analyses reveal differential gene expression patterns between the life-cycle stages of Emiliania huxleyi (Haptophyta) and reflect specialization to different ecological niches. J. Phycol. 47: 829-38

Rokitta SD, Von Dassow P, Rost B, John U. 2014. Emiliania huxleyi endures Nlimitation with an efficient metabolic budgeting and effective ATP synthesis. BMC Genomics 15: 14

Rose SL, Fulton JM, Brown CM, Natale F, Van Mooy BAS, Bidle KD. 2014. Isolation and characterization of lipid rafts in Emiliania huxleyi: a role for membrane microdomains in host-virus interactions. Environ. Microbiol. 16: 1150-66

Rosenwasser S, Mausz MA, Schatz D, Sheyn U, Malitsky S, et al. 2014. Rewiring host lipid metabolism by large viruses determines the fate of Emiliania huxleyi, a bloom-forming alga in the ocean. Plant Cell 26: 2689-707

Rost B, Riebesell U. 2004. Coccolithophores and the biological pump: responses to environmental changes In Coccolithophores, from Molecular Processes to Global Impact, ed. HR Thierstein, JR Young, pp. 99-125. Heidelberg: Springer

Rost B, Zondervan I, Wolf-Gladrow D. 2008. Sensitivity of phytoplankton to future changes in ocean carbonate chemistry: current knowledge, contradictions and research directions. Mar. Ecol. Prog. Ser. 373: 227-37

Sand KK, Pedersen CS, Sjöberg S, Nielsen JW, Makovicky E, Stipp SLS. 2014. Biomineralization: Long-term effectiveness of polysaccharides on the growth and dissolution of calcite. Cryst. Growth Des. 14: 5486-94 
Savoca MS, Nevitt GA. 2014. Evidence that dimethyl sulfide facilitates a tritrophic mutualism between marine primary producers and top predators. Proc. Natl. Acad. Sci. USA 111: 4157-61

Schatz D, Shemi A, Rosenwasser S, Sabanay H, Wolf SG, et al. 2014. Hijacking of an autophagy-like process is critical for the life cycle of a DNA virus infecting oceanic algal blooms. New. Phytol. 204: 854-63

Segev E, Castaneda IS, Sikes EL, Vlamakis H, Kolter R. 2016. Bacterial influence on alkenones in live microalgae. J. Phycol. 52: 125-30

Seyedsayamdost MR, Case RJ, Kolter R, Clardy J. 2011. The Jekyll-and-Hyde chemistry of Phaeobacter gallaeciensis. Nat. Chem. 3: 331-5

Seyedsayamdost MR, Wang R, Kolter R, Clardy J. 2014. Hybrid biosynthesis of roseobacticides from algal and bacterial precursor molecules. J. Am. Chem. Soc. 136: 15150-3

Seymour JR, Simo R, Ahmed T, Stocker R. 2010. Chemoattraction to dimethylsulfoniopropionate throughout the marine microbial food web. Science 329: 342-5

Sharoni S, Trainic M, Schatz D, Lehahn Y, Flores MJ, et al. 2015. Infection of phytoplankton by aerosolized marine viruses. Proc. Natl. Acad. Sci. USA 112: 6643-47

Siever R. 1992. The silica cycle in the Precambrian. Geochim. Et Cosmochim. Acta 56: 3265-72

Spero HJ, Eggins SM, Russell AD, Vetter L, Kilburn MR, Honisch B. 2015. Timing and mechanism for intratest $\mathrm{Mg} / \mathrm{Ca}$ variability in a living planktic foraminifer. Earth. Planet. Sci. Lett. 409: 32-42

Steinke M, Stefels J, Stamhuis E. 2006. Dimethyl sulfide triggers search behavior in copepods. Limnol. Oceanogr. 51: 1925-30

Steinke M, Wolfe GV, Kirst GO. 1998. Partial characterisation of dimethylsulfoniopropionate (DMSP) lyase isozymes in 6 strains of Emiliania huxleyi. Mar. Ecol. Prog. Ser. 175: 215-25

Stiller JW, Schreiber J, Yue J, Guo H, Ding Q, Huang J. 2014. The evolution of photosynthesis in chromist algae through serial endosymbioses. Nat. Commun. 5: 5764

Suffrian K, Schulz KG, Gutowska MA, Riebesell U, Bleich M. 2011. Cellular pH measurements in Emiliania huxleyi reveal pronounced membrane proton permeability. New. Phytol. 190: 595-608

Sunda W, Kieber DJ, Kiene RP, Huntsman S. 2002. An antioxidant function for DMSP and DMS in marine algae. Nature 418: 317-20

Sviben S, Gal A, Hood MA, Bertinetti L, Politi Y, et al. 2016. A vacuole-like compartment concentrates a disordered calcium phase in a key coccolithophorid alga. Nat. Commun. 7: 11228

Takagi H, Moriya K, Ishimura T, Suzuki A, Kawahata H, Hirano H. 2015. Exploring photosymbiotic ecology of planktic foraminifers from chamber-by-chamber isotopic history of individual foraminifers. Paleobiology 41: 108-21

43

44

45

46

Taylor AR, Brownlee C. 2016. Calcification In The Physiology of Microalgae, ed. AM Borowitzka, J Beardall, AJ Raven, pp. 301-18. Cham: Springer International Publishing 
Taylor AR, Chrachri A, Wheeler G, Goddard H, Brownlee C. 2011. A voltage-gated H+ channel underlying $\mathrm{pH}$ homeostasis in calcifying coccolithophores. PLoS Biol. 9

Taylor AR, Russell MA, Harper GM, Collins TfT, Brownlee C. 2007. Dynamics of formation and secretion of heterococcoliths by Coccolithus pelagicus ssp.braarudii. Eur. J. Phycol. 42: 125-36

Trimborn S, Langer G, Rost B. 2007. Effect of varying calcium concentrations and light intensities on calcification and photosynthesis in Emiliania huxleyi. Limnol. Oceanogr. 52: 2285-93

Tsuji Y, Yamazaki M, Suzuki I, Shiraiwa Y. 2015. Quantitative analysis of carbon flow into photosynthetic products functioning as carbon storage in the marine coccolithophore, Emiliania huxleyi. Mar. Biotech. 17: 428-40

Tyrrell T, Merico A. 2004. Emiliania huxleyi: bloom observations and the conditions that induce them. Berlin: Springer-Verlag Berlin. 75-97 pp.

Unrein F, Gasol JM, Not F, Forn I, Massana R. 2014. Mixotrophic haptophytes are key bacterial grazers in oligotrophic coastal waters. ISME J. 8: 164-76

Van Oostende N, Moerdijk-Poortvliet TC, Boschker HT, Vyverman W, Sabbe K. 2013. Release of dissolved carbohydrates by Emiliania huxleyi and formation of transparent exopolymer particles depend on algal life cycle and bacterial activity. Environ. Microbiol. 15: 1514-31

Vardi A, Haramaty L, Van Mooy BA, Fredricks HF, Kimmance SA, et al. 2012. Hostvirus dynamics and subcellular controls of cell fate in a natural coccolithophore population. Proc. Natl. Acad. Sci. USA 109: 19327-32

Vardi A, Van Mooy BAS, Fredricks HF, Popendorf KJ, Ossolinski JE, et al. 2009. Viral glycosphingolipids induce lytic infection and cell death in marine phytoplankton. Science 326: 861-65

von Dassow P, John U, Ogata H, Probert I, Bendif E, et al. 2015. Life-cycle modification in open oceans accounts for genome variability in a cosmopolitan phytoplankton. ISME J. 9: 1365-77

von Dassow P, Ogata H, Probert I, Wincker P, Da Silva C, et al. 2009. Transcriptome analysis of functional differentiation between haploid and diploid cells of Emiliania huxleyi, a globally significant photosynthetic calcifying cell. Genome Biol. 10

Ward BA, Follows MJ. 2016. Marine mixotrophy increases trophic transfer efficiency, mean organism size, and vertical carbon flux. Proc. Natl. Acad. Sci. USA

Weitz JS, Stock CA, Wilhelm SW, Bourouiba L, Coleman ML, et al. 2015. A multitrophic model to quantify the effects of marine viruses on microbial food webs and ecosystem processes. ISME J. 9: 1352-64

Westbroek P, Young JR, Linschooten K. 1989. Coccolith production (biomineralization) in the marine alga Emiliania huxleyi. J. Protozool. 36: 36873

Wilken S, Huisman J, Naus-Wiezer S, Van Donk E. 2013. Mixotrophic organisms become more heterotrophic with rising temperature. Ecol. Lett. 16: 225-33 
1 Wilson WH, Schroeder DC, Allen MJ, Holden MTG, Parkhill J, et al. 2005. Complete

2 genome sequence and lytic phase transcription profile of a Coccolithovirus.

3 Science 309: 1090-92

4 Winter A, Jordan JR, Roth PH. 1994. Biogeography of living coccolithophores in

$5 \quad$ ocean waters

6 In Coccolithophores, ed. A. Winter, WG Siesser, pp. 161-78. Cambridge Cambridge

$7 \quad$ University Press

8 Wolfe GV, Steinke M, Kirst GO. 1997. Grazing-activated chemical defence in a

9 unicellular marine alga. Nature 387: 894-97

10 Xu K, Gao K, Villafane VE, Helbling EW. 2011. Photosynthetic responses of Emiliania huxleyi to UV radiation and elevated temperature: roles of calcified coccoliths. Biogeosciences 8: 1441-52

Xu K, Gao KS. 2012. Reduced calcification decreases photoprotective capability in the coccolithophorid Emiliania huxleyi. Plant Cell Physiol. 53: 1267-74

Young JR. 1994. Functions of coccoliths In Coccolithophores, ed. A Winter, WG Siesser. Cambridge: Cambridge University Press

Young JR, Andruleit H, Probert I. 2009. Coccolith function and morphogenesis: Insights from appendage-bearing coccolithophores of the family syracosphaeraceae (Haptophyta). J. Phycol. 45: 213-26

Young JR, Davis SA, Bown PR, Mann S. 1999. Coccolith ultrastructure and biomineralisation. J. Struct. Biol. 126: 195-215

Young JR, Geisen M, Probert I. 2005. Review of selected aspects of coccolithophore biology with implications for paleobiodiversity estimation. Micropaleontol. 51: 267-88

Young JR, Westbroek P. 1991. Genotypic variation in the coccolithophorid species Emiliania huxleyi. Mar. Micropaleont. 18: 5-23

Ziveri P, de Bernardi B, Baumann K-H, Stoll HM, Mortyn PG. 2007. Sinking of coccolith carbonate and potential contribution to organic carbon ballasting in the deep ocean. Deep-Sea Res. Pt. II 54: 659-75 